\title{
Combining micro-bottom-up and macro-top-down modelling responses to nutrient cycles in complex agricultural systems
}

\author{
Robert P. Burdock · John W. Crawford
}

Received: 31 December 2014/ Accepted: 27 September 2015/Published online: 24 October 2015

(C) The Author(s) 2015. This article is published with open access at Springerlink.com

\begin{abstract}
Concerns over the long-term sustainability of the food production system and the nutritional content of food from mineral depleted soils have encouraged a policy shift to sustainable agricultural practices where soil health supports nutrition-sensitive agriculture. Interventions at the micro scale have the ability to affect the entire system, forcing an examination at the whole of systems level. Modelling plays an important role in determining the outcomes of policy intervention combinations, particularly when systems are identified as being complex. This study begins with a systems map tracing the nutrient cycling process between natural ecosystem processes and farm practices from the bottom-up within a top-down framework. Soil is at the centre of this approach, expanding links to other influences within the framework in order to understand the relationships between elements in an environmental-agricultural system. Moving to a generic model from a broad conceptual system map is problematic when crop types, plant mineral absorption rates, soil and geographic differences are to be accommodated. Work has been done to
\end{abstract}

R. P. Burdock ( $\square)$

The Faculty of Agriculture and Environment, University of Sydney, Sydney, NSW 2006, Australia

e-mail: rob.burdock@sydney.edu.au

J. W. Crawford

Rothamsted Research, West Common,

Harpenden, Hertfordshire AL5 2JQ, UK

e-mail: john.crawford@ rothamsted.ac.uk develop top-down framework models integrating bottom-up component models, capable of being used in different scenarios. Whether existing models are used or new models are created, this study recommends that an appropriate modelling response require examination of systems and policy interventions both holistically and in detail encompassing situational specifics.

Keywords Complex systems · Nutrition cycle · Agriculture $\cdot$ Modelling

\section{Introduction and objectives}

Food is a product of the environment, either harvested from an aqua/agricultural system or directly from nature. Further, food in a developed society is often processed, packaged and presented to satisfy hunger, taste and preference. It provides energy and essential nutrients for healthy living. It can define culture, lifestyle and status, and brings together community, friendship and commerce. The growing of food is the story of a complex process.

It is well documented that the long-term sustainability of the food production system is threatened. Some examples of the system in crisis include: unsustainable water withdrawals for agriculture (UN-Water 2009; FAO 2012) the loss of land productivity following degradation from overgrazing 
of marginal land (Geist and Lambin 2004; Slimani et al. 2010; Alemseged et al. 2011; Zhou et al. 2011); decreasing fish yields as the globalised trade in aquatic farming exacerbates the spread of disease from the intensive farming of aquatic livestock (Stentiford et al. 2012); soil nutrient deficiency and the collective damage to the environment of processes connected with intensive mono-cropping (Watson et al. 2002; Ball et al. 2005; Govaerts et al. 2007); and the loss of free ecosystem services, for example from bees which naturally help to pollinate crops (Kremen et al. 2002; Brown and Paxton 2009). Land degradation alone is predicted to reduce global yields by $30 \%$ in the next 20-50 years (Pimentel 2006) during which time, global demand will require yield increases of $40 \%$ (Beddington 2010).

The nutritional value within the agricultural product before it enters the processing chain is also approaching a crisis. Some examples include a loss of soil fertility which impacts the nutritional quality of plants grown (St Clair and Lynch 2010; Lai 2009); deteriorating animal nutrition derived from a diet limited in variety in domesticated livestock (Poulson et al. 2004; Villalba et al. 2010); the shift to formulate animal feed to modify and accelerate the growth of the produce (Adams 2006); and for human food consumption, there is a reduction in nutritional health where the menu of a once wide variety of foods offered in nature is now limited to the food choices commonly farmed (Hodgson et al. 1994; Tucker 2001; Michels and Wolk 2002; Hughes and Dhiman 2002; Larsen 2003). It is estimated that one third of humanity suffers from the effects of poor nutrition and obesity. For example, more than one third of preschool-age children globally are Vitamin A deficient due to a diet lacking in nutritionally active carotenoids (the colorful organic pigments found in edible plants such as fruit and vegetables) (World Health Organisation 2004). More than 1.5 billion people are considered overweight worldwide, of whom 500 million are obese (World Health Organisation 2012). As developing countries consume more meat in combination with high-sugar and high-fat foods, they may find themselves having to deal with obesity before they have overcome the limitations of a nutritionally poor diet, leading to an increase in spending on health that could otherwise be used to alleviate poverty (Godfray et al. 2010).
Compounding the issue is that the human genome has not had time to adjust over the last 10,000 years to our new and narrower diet following the introduction of agriculture and farm animal domestication (Cordain et al. 2005). Today, the availability of convenient, energy dense, ready-to-eat meals further disconnects the hungry consumer from the source and preparation of his/her food.

There is a distinction in roles and activities between those who produce raw food and those who process it. To produce sustainable food implicates a complex system with cycles and interactions linking environmental systems, agricultural systems and the systems of commercial food preparation and delivery into a complex web. The food system incorporates the entire food supply industry, including branded processed food products and the retail chains selling them. Added to this is the off-farm treatment of raw food by commercial food processing manufacturers and retailers. Cultural preferences and the socio-economic cycle also need to be considered (Campbell et al. 2009). The production of raw food from the farm, or as is harvested from nature, is one subsection of the food system. The food system is shown in Fig. 1.

Research integrating agriculture and the environment (Kaine and Tozer 2005; Pfister et al. 2005) as well as agriculture and nutrition (Fynn et al. 1989; Dangour et al. 2012) has been useful for understanding the relationships and predicting the outcomes of interventions. The combination of a broader environmental-agricultural-societal nexus to incorporate a nutrition-sensitive food system and a balanced diet to sustain human health does not appear to be comprehensibly modelled (Sobal et al. 1998; Cannon and Leitzmann 2005; Allen et al. 2014). This has been identified as necessary (Ingram 2011; Keding et al. 2013), including as a key conclusion from the 1st International Global Food Security Conference in 2013 (Dogliotti et al. 2014). A predictive model of this type and magnitude would be extremely complex and challenging (Penders et al. 2009).

The examination in this paper is limited to the point at which the food stock departs the influence of where it is grown, harvested or slaughtered. The food production system therefore refers to the agricultural system and its relationship with the broader environment, and does not include food processing, supply chains, food retail, or food preparation in the broader food system. What is highlighted is the importance of 


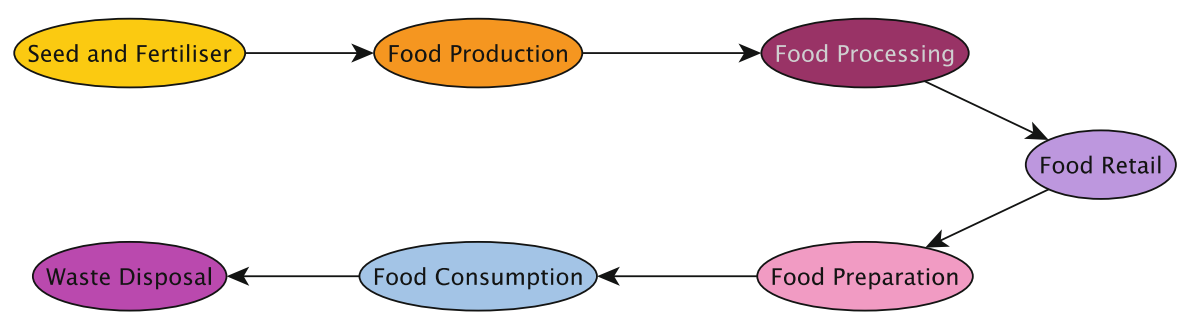

Fig. 1 The food system and the food supply chain. The food system encompasses all elements of food from source, through consumption to waste disposal. The food production system is a

the nutrition cycle, including the return of micronutrients from society back into agricultural-environmental system. A sustainable food production system is one that can inter-generationally, provide both adequate nutrition and supply appropriate energy to people in society, and enhance the natural environment in which it is produced.

Modelling plays an important role to explore the outcomes of policy intervention combinations. The purpose of this study is to suggest an appropriate modelling response to identify food nutritional outcomes from complex agricultural systems. Following an understanding of the basics of complex systems behaviour, a map is created, charting the influences contributing to the micronutrient cycle from soil to food within an environmental and agricultural system relationship. The following discussion concerns the suitability of either a top-down or bottom-up modelling approach to incorporate nutrient cycling for sustainable food production.

\section{Systems}

A systems approach

Identifying the type of system (simple, complicated, complex) is an important first step in resolving systems problems. While systems thinking does not necessarily lead to better decision making, the type of system being considered may be more relevant to better decision making (Choi et al. 2001; Kurtz and Snowden 2003; Maani and Maharaj 2004). When a systems perspective is used, we are more inclined to recognise and address the problem with system-wide solutions, ensuring that all elements are considered (Burdock and Crawford 2012). All these interactions sub-section of the entire system, and is limited to the agricultural system and its broader environment

must be understood collectively so that the emerging issues are appropriately addressed.

As simple systems become more complicated and complex, the functions of the elements within the system become subtler and less able to be understood. The risk of function failure can be defined, quantified and understood by modelling the system where the states of the system constitute the essence of the analysis (Haimes 2009).

It takes time for a system to be regarded as sustainable (Rigby and Caceres 2001) as the impacts of any interference in a system may not be immediate. Thus the dimensions of both space and time are to be incorporated in a suitable modelling approach. What follows is a brief revision of simple, complicated and complex systems to support appropriate system responses.

Simple, complicated and complex systems

There are fundamental differences between simple, complicated and complex systems, as there are with the appropriate responses to address them. Simple systems have an obvious linear cause and effect relationship between system elements, encouraging a "best practice" response. This would be one in which the problem solver would sense the problem, categorise it, then respond to it. This is demonstrated in Fig. 2.

Complicated problems are less obvious. There may be more elements interacting and while it is possible to

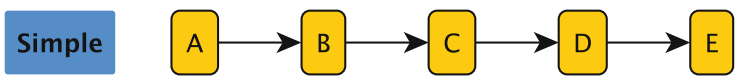

Fig. 2 A simple system. Cause and effect relationships are linear and easily understood 
identify the role each element plays in the system, the overall behaviour may result from a contribution of many of the elements. Models can be introduced to aid intuition. A complicated problem would be one in which the problem solver would sense the problem, analyse it, then respond to it, providing a "good practice" response (Kurtz and Snowden 2003). To make a complicated system simple will make it more easily understood. This is demonstrated in Fig. 3.

Complex problems hold a non-linear relationship between the elements in the system with many feedback loops. This is demonstrated in Fig. 4.

In complex systems, cause and effect relationships cannot necessarily be attributed to a single element. Instead, system behaviour results from the collective interactions between the elements whereby it is the nature of the interactions that takes precedence. It will be the loss of the function of an element and its functional relationship with other elements that will impact the resilience of a complex system (Allen et al. 2005; Deffuant and Gilbert 2011).

To simplify a complex problem by omitting these interactions will most likely make it dysfunctional. Complex system element relationships and interactions are unique, as each complex system will behave differently. A universally applied "best" practice will not fit a unique system (Kurtz and Snowden 2003). Studies in network topography and in drug pathways that influence the cell cycle provide useful examples for understanding the nature of complex systems (Clyde et al. 2006; Faratian et al. 2009; Liu et al. 2011).

Complex systems theory, agriculture and ecosystems

The multiple feedback loops give a complex system strength providing resilience, efficiency in resource preservation, and efficiency in functionality. With increasing complexity, the self-organising nature of a complex system will find a position between order and disorder, which is resilient within boundaries to

\section{Complicated}

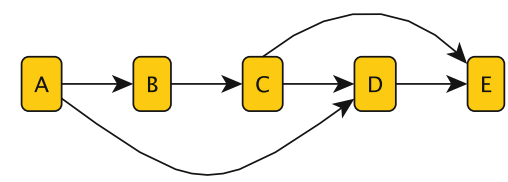

Fig. 3 A complicated system. Cause and effect relationships are linear and but to understand the overall functioning behaviour of the system requires an analytical response

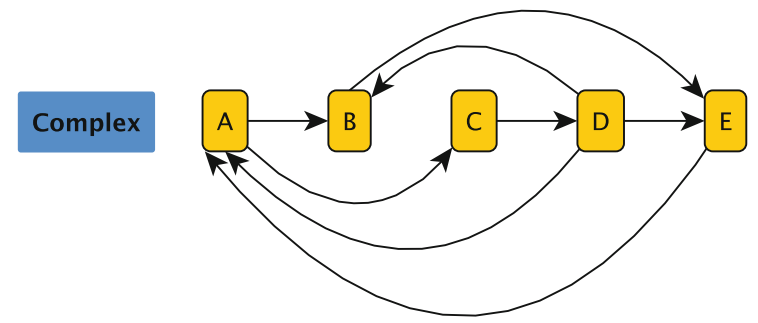

Fig. 4 A complex system. Cause and effect relationships are non-linear with many relationship feedback loops

shocks (Parrott 2010). For example, monoculture farming is a human induced shock to an ecosystem that creates a temporary order which, when abandoned will move to a more complex structure. The greater the complexity of the system, the more likely the system will be to survive. For example, a shock to a single crop farming system such as a lack of water from rainfall in an annual season is more likely to result in a collapse of the system, than will be the same shock to a complex rainforest on the same landscape in the same period. The preservation of ecosystem complexity and function can in many cases aid in mitigating the effects of extremes in weather, enhancing vital services such as water retention. For example, the correlation between vegetation functionality and surface temperature variance suggests a positive correlation between complex biodiversity and dissipative capacity of incoming stress (Schneider and Kay 1994; Norris et al. 2012). The threat of system collapse is greater when the system is subjected to coordinated shocks to particular nodes without enough time for resilience to adjust to a new efficiency (Butzer and Endfield 2012).

\section{Mapping the environmental and agricultural system relationships in order to trace nutrient cycling}

Mapping: the first step to designing an appropriate model

To help understand the connectivity across the environmental and agricultural system interface and to trace nutrition flows, the web of relationships is mapped as a first step to model this complexity and to assess the shape of the network. This is limited to terrestrial interactions. 
Food must provide energy and promote health. In the developed world, food production tends to focus on crop yield and energy density at the expense of nutrition (Morris and Sands 2006; Halweil 2007;), yet it is encouraging that some research is being conducted into enhancing the nutritional value of food grown (Bouis 2002; Welch and Graham 2004; White and Brown 2010). Additionally, there are moves to consider biodiversity and environmental security in nutritional guidelines whereby not just the nutritional content of the food is examined, but also the methods by which it is sourced. (Wahlqvist 2004; Byron et al. 2011).

To ensure that health remains central to the sustainable food production system, this map begins with nutrition. Nutrition is a story of vitamins and minerals (Geissler and Powers 2005). It is from the soil that plants derive water, minerals and when growing, they develop vitamins pertinent to the plant, its fruit, its leaves and its roots (Grusak and DellaPenna 1999; Zhu 2009; White and Brown 2010). Soil then is the starting point for a map of the whole model.

\section{Soil nutrient cycle}

The soil mineralisation cycle is made up of microorganisms, which break down dead biomass and mineralise it into an organic store. Plants, fungi and other life then absorb this to continue the cycle. A schematic is shown in Fig. 5 (Marschner and Rengel 2007). The soil nutrient system cycle is at the heart of this map. To highlight the importance of this cycle, slightly thicker connections are used and the connection labels remain for reference as the map is developed.

Contributing to the cycles leading to soil health are soil moisture content $\left(\mathrm{H}_{2} \mathrm{O}\right)$, carbon $(\mathrm{C})$, nitrogen $(\mathrm{N})$, phosphate $(\mathrm{P})$, and the acidic/alkaline $(\mathrm{pH})$ balance as well as the influence of existing micronutrients in the soil. Other mineral elements required for plant growth include macronutrients potassium $(\mathrm{K})$, calcium $(\mathrm{Ca})$, magnesium $(\mathrm{Mg})$, sulphur $(\mathrm{S})$, and micronutrients chlorine $(\mathrm{Cl})$ boron $(\mathrm{B})$, iron $(\mathrm{Fe})$ manganese $(\mathrm{Mn})$, copper $(\mathrm{Cu})$, zinc $(\mathrm{Zn})$, nickel $(\mathrm{Ni})$ and molybdenum (Mo), referenced as Other Nutrients in the diagram in Fig. 6 below. There is a detrimental effect on plant growth if any one of these minerals is missing. Some minerals such as $\mathrm{N}$ and $\mathrm{P}$ are required in larger amounts while only trace elements are required of minerals such as $\mathrm{Fe}$ and $\mathrm{Zn}$. Thus, healthy soil supports the growth of healthy plants (White and Brown 2010). While not always necessary for growth, plants will also take in other micronutrients if they are in the soil such as selenium (Se), and iodine (I). When plant matter dies or falls from the plant (leaf litter for example), it contributes to the biomass store (Helfrich et al. 2008; Nielsen et al. 2011). Soils rich in mineralised inorganic mass provide the opportunity for the uptake of these minerals into the plants (Gupta et al. 2008). This cycle is shown in Fig. 6.

Natural ecosystem processes

Critical to the system are the dynamics of natural ecosystem processes. Latitude, altitude, climate,

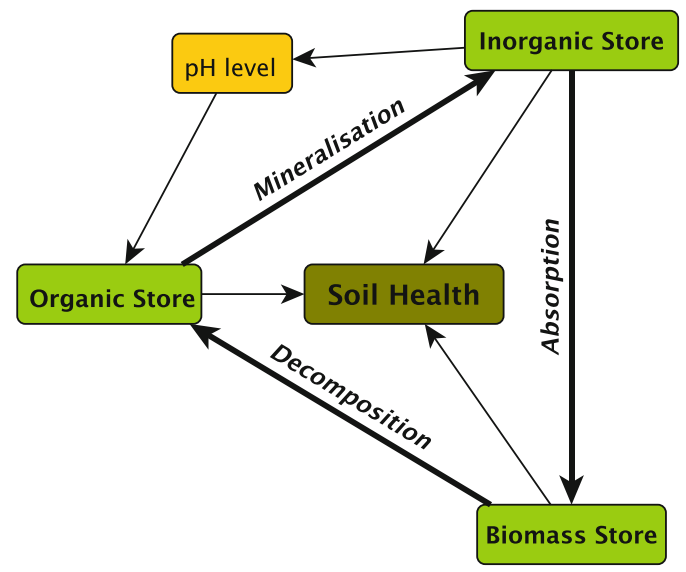

\begin{tabular}{|c|}
\hline COLOUR LEGEND \\
\hline Ecosystem Processes \\
\hline Soil Health \\
\hline Nutrients \\
\hline
\end{tabular}

Fig. 5 Map of the soil system. Organic matter in the soil decomposes biomass, mineralising it for uptake and absorption by plants 

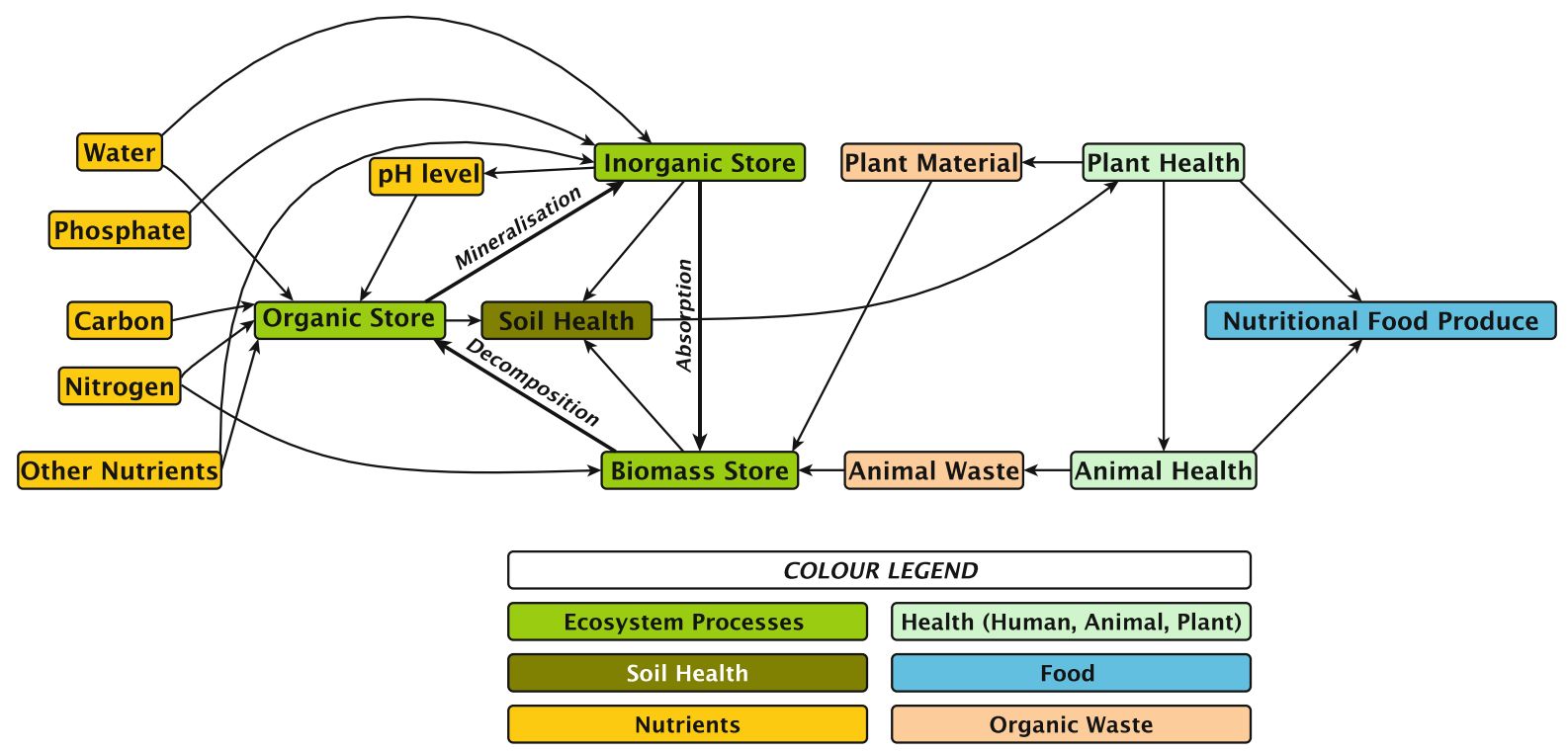

Fig. 6 Map of the soil and nutrient system. Mineral nutrients in soil are absorbed by plants. Plants develop vitamins and pass on the minerals and vitamins to the animals (including humans) who eat them. All dead matter on the soil surface is decomposed to continue the cycle

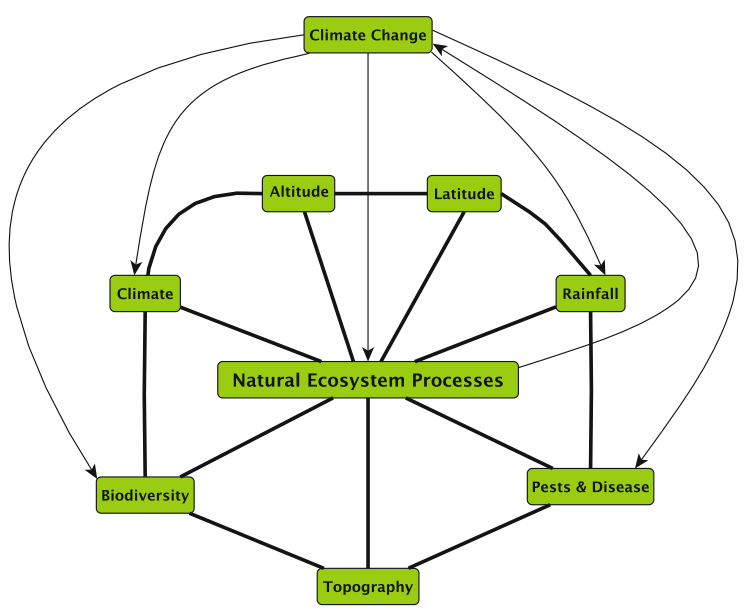

Fig. 7 Map of the natural ecosystem processes. There is a relationship between topography, geography, climate, biodiversity and disease contributing to natural ecosystem processes

harvest as crop residue, after livestock has consumed surface vegetation, and from the return of nutrient rich biomass to the soil. Additionally, the choice to grow a high yielding plant variety can be a trade off between yield and crop nutrient content (Mayer 1997; Davis et al. 2004; Davis 2009; Gooding et al. 2012). Other variables will include a mixed and rotational approach to cropping and animal production, intensive 
agriculture, use of synthetic or organic soil fertiliser, herbicide and pesticide use, tillage practices and water application through irrigation (Bontkes and van Keulen 2003; Holland 2004; Vitousek et al. 2009; Sauer et al. 2010; Mediene et al. 2011; Powlson et al. 2011). These relationships are shown in Fig. 8.

Three pillars of human health

Pillars supporting human health involve a relationship between nutrition, exercise and sleep (Harris et al. 2005; Resnick et al. 2006;). Eating nutritionally dense food provides the body with the vitamins and minerals required for maintenance and replacement of cells and tissue (Mertz 1994). There are a total of 19 mineral trace micronutrients needed for human health. In addition to the 15 micronutrients listed above that are required in the soil for plant growth, the minerals iodine (I) selenium ( $\mathrm{Se}$ ) cobalt (Co), and chromium (Cr) are required in trace form in the food of the human diet. An absence of any of these and earlier mentioned micronutrients will have long-term health consequences (WHO 2004).

Data suggests a strong relationship between sleep restriction, weight gain and the risk of diabetes, connected with diet and exercise (Knutson et al. 2007). Restful sleep provides the body with time to repair damaged cells and improves brain function (Halson 2008; Mignot 2008). The energy in food supports physical activity. A regular periodic increase in physical activity is essential to good health, particularly when modern living allows a relatively sedentary life when compared with that experienced during our evolution. Vigorous activity is able to mildly stress the

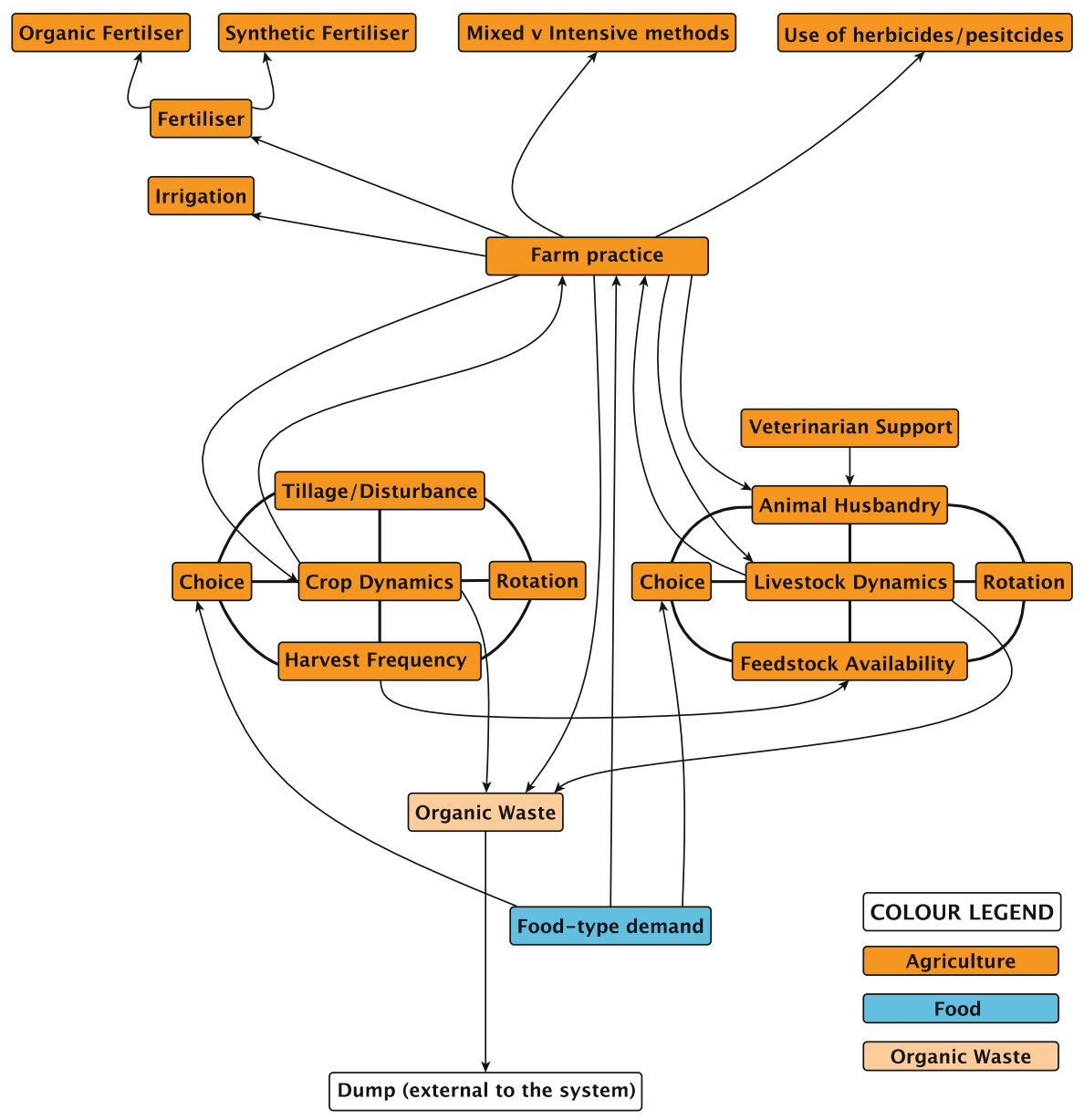

Fig. 8 Map of farm practices. Livestock and crop dynamics have a mutually complementary relationship with management practices and farming methods 
body to encourage strength in all the organs as well as to stimulate the supply of oxygen for cell regeneration throughout the body (Tanji 2000; Penedo and Dahn 2005; Swain and Franklin 2006). These three "pillars" are shown in Fig. 9.

To complete the total food system, there are other links into society from here with their own systems, including the food processing industry and the outcome of consumer food choices (Furst et al. 1996; Sobal et al. 1998). The United Kingdom's Foresight, Tackling Obesities: Future Choices Project maps the connections between food choice, food psychology and attitude to food consumption, exercise opportunity and human physiology providing a good example of integrated systems with a focus on obesity outcomes (Butland et al. 2007a). These are recognised as systems in their own right and while they contribute to a greater awareness of human health, they are beyond discussion here. What is relevant to recognise is that feedback loops from these extended systems will influence this system being mapped.

Recycling of organic waste

The distribution of nutrients has diminished since the end of the Pleistocene, a time when megafauna is thought to have supported nutrient dispersal across the broader landscape (Doughty et al. 2013). This is exacerbated with human concentration of $\mathrm{N}$ and $\mathrm{P}$ nutrients into agricultural land and from society's poor recycling of organic waste. Food not eaten, scraps discarded during the preparation of food, and human waste is generally not cycled back into the system, particularly from an urbanised society. Rather, organic waste tends to be deposited into landfill or treated and flushed into the oceans (Schultz and Romheld 1997; Esrey 2001; Refsgaard and Magnussen 2009). It is estimated that approximately one-third of all food produced for human consumption in the world is lost or wasted (FAO 2013). Not only is this wasted food contributing needlessly to environmental degradation, resource depletion and greenhouse gas pollution, but it too is not recycled into agricultural land.

While it is recognised that there are many influences on this integrated system, which are not captured here, a map such as this shows a loss of micronutrients from the system. The box at the very bottom of the map in Fig. 8 and in Fig. 10 titled "Dump (external to the system)" highlights a loss to the system of organic waste. By removing the plants and animals for consumption and not returning our own "litter" to the soil, we break the feedback loop. Without recycled nutrients, soil loses its micronutrient fertility. Modern agriculture compensates with

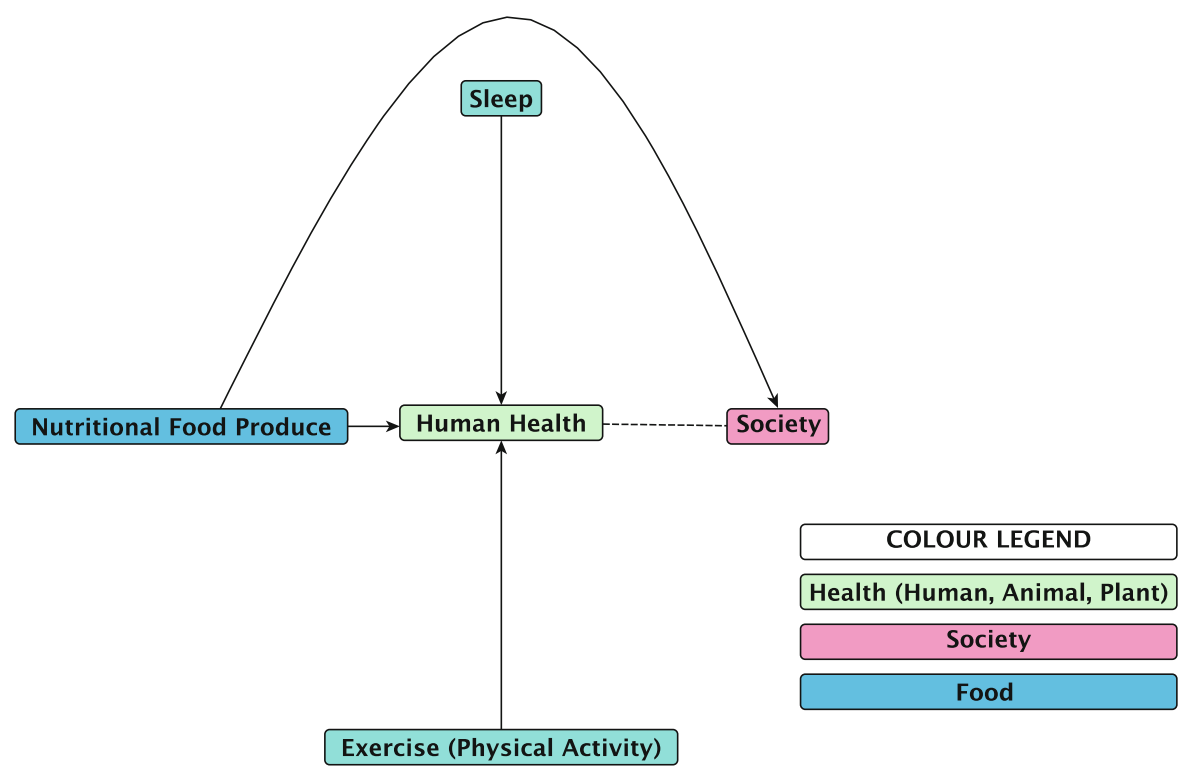

Fig. 9 Map linking aspects of human health. Nutritional food works with physical activity and sound sleep to contribute to human health 


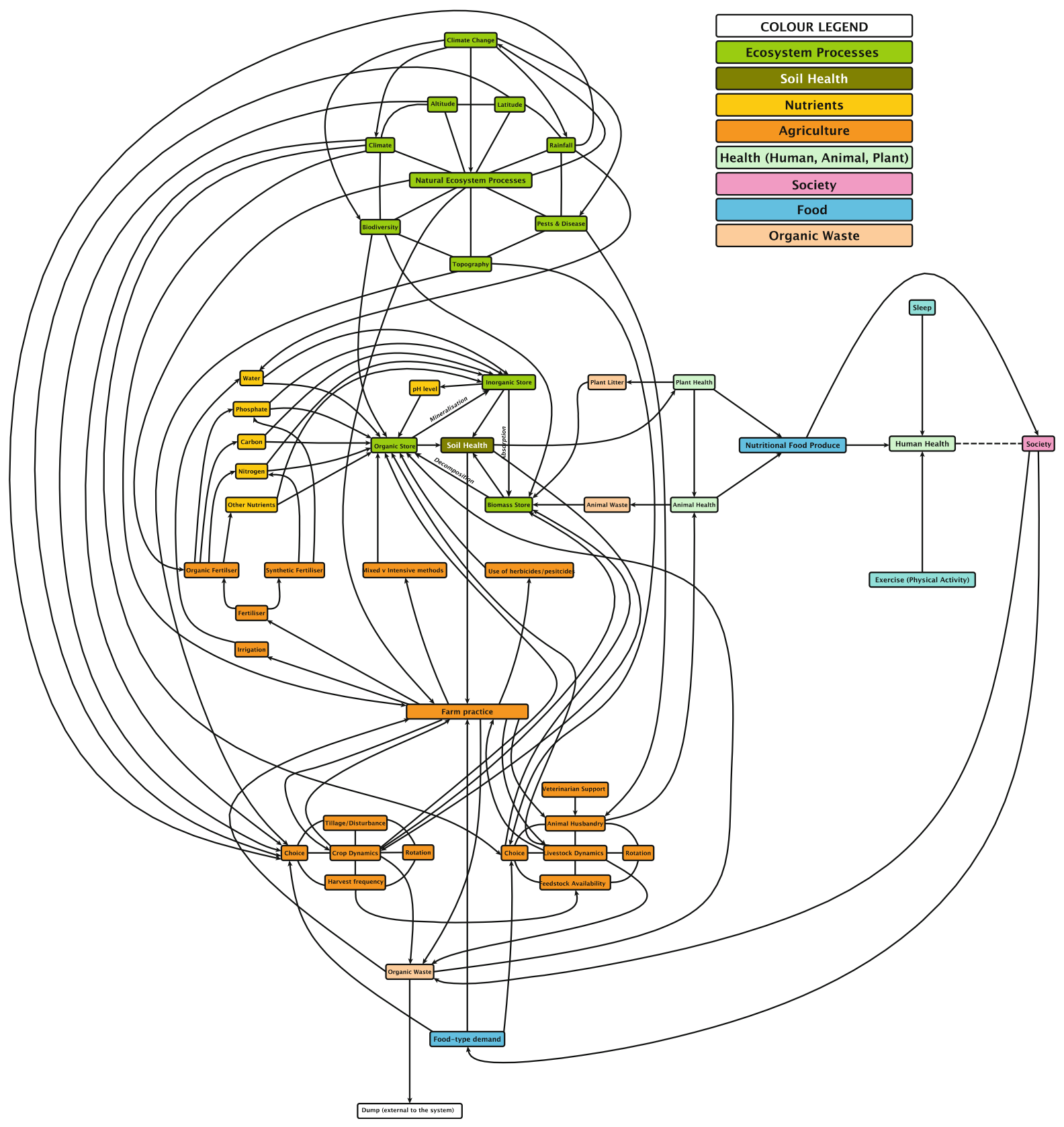

Fig. 10 Map integrating environmental, agricultural and nutritional systems. This map models the key relationships between various elements in the environmental-agricultural relationship with a nutritional perspective

artificial interventions such as synthetic fertilisers which, when coupled with herbicides and pesticides, have dramatically increased the yield of crops and pasture, but do not necessarily improve soil health. The use of artificial interventions is a financial expense for farmers and comes at a cost to the soil microbial environment. For example, the fungal to bacterial biomass ratio has been found to be consistently and significantly higher in unfertilised than fertilised grasslands (Bardgett and McAlister 1999). Cu fungicides are particularly toxic to soil organisms. An important indirect effect of $\mathrm{N}$ fertiliser use is soil 
acidification (Bunemann et al. 2006) with the consequential result reducing microbial activity. A loss of soil organic matter causes $\mathrm{CO}_{2}$ release, reduces soil resilience and forces a greater dependence on the increasingly expensive artificial stimulants required to maintain current yields (Powlson et al. 2000), impacting both the nutritional value of the soil and the ability of the system to be self-sustaining (Hobbs and Norton 1996).

Linking the environment and agriculture to healthy food

All the figures for this system are drawn together in Fig. 10. Soil remains at the centre of this map, as it is from soil that plants grow, creating the mineral and vitamin supply process into food. At the top of the map are the dynamics of natural ecosystem processes that predominantly link with soil inputs and farming practices at the bottom of the map. There are feedback loops from farming practices that influence the health of the soil. The outputs from soil lead to nutritional density in plants and through plants to the animals we eat.

Visualising the key interactions

This map can be overwhelming to read at first glance. Social network analysis uses network and graph theories to trace structures between actors in a network. Ties between the actors are connected with lines to show the network of connections giving a visual representation of the relationships. Finegood et al. (2010) used social network analysis (de Nooy et al. 2005) to visualise the relative importance of the interactions between key elements of the Foresight, Tackling Obesities: Future Choices Project (Butland et al. 2007a). This project sought to understand how the food system contributes to obesity by mapping system relationships. It scaled up system interactions between the clusters of food supply, exercise and movement, energy expenditure, human physiology, and food psychology to achieve a conceptual systemwide framework (Butland et al. 2007a). Using the similar techniques, the integrated food system map can be represented as shown in Fig. 11.

Connections between clusters in the reduced map reflect the number of individual connections between the variables in each cluster of the full map. The width of the arrow is proportional to the number of underlying connections. For example, the thickest arrow links Natural Ecosystem Processes to Farm Practice, reflecting 10 direct influences from the Natural Ecosystem Processes to Farm Practice. The thick border around Farm Practice reflects that there are 31 interconnections among the variables in this cluster, whereas the thin boarder around Society reflects only two interconnections among the variables in this cluster of the map. The predominant feedbacks are clearly illustrated.

The complex map was deliberately written as a flow of nutrition to society. There are other links with different functions, which are not included here. For example, the impact of the Natural Ecosystem Processes will affect other aspects of Society, however for food specifically, it will be via the soil cycle. Using this simplified visual approach, what happens in the natural environment can be clearly observed to be highly influential to practices on the farm. So too it can be easily observed that soil health is significantly influenced by practices on the farm.

Using line and box thickness, the volume of relationships is more easily noticed, however while the line thickness might reflect the complexity, it does not necessarily reflect the importance of the interacting links in the system relationships. A single connection may be critical to support a process, for example, the recycling of human organic waste from Society to the Farm Practice would contribute significantly to the maintenance of sustained soil nutrient health and remineralisation of farming land. This exercise is useful for identifying the volume of interactions, but not necessarily the quality of functional relationships, highlighting a risk for simplifying complex problems. Structuring complex systems well by using techniques such as multi criteria decision analysis and social network analysis to weigh the importance of the relationships in the system would be a valuable contribution to a future development of this map for further system understanding. Such an indepth study is beyond the scope of this paper.

Tracing the flow of soil nutrient cycling

Revisiting the complete map in Fig. 10, a cycle is highlighted where the biomass in organic waste is returned to the soil and a case where it is not. The highlighted area on Fig. 12 shows that when the 


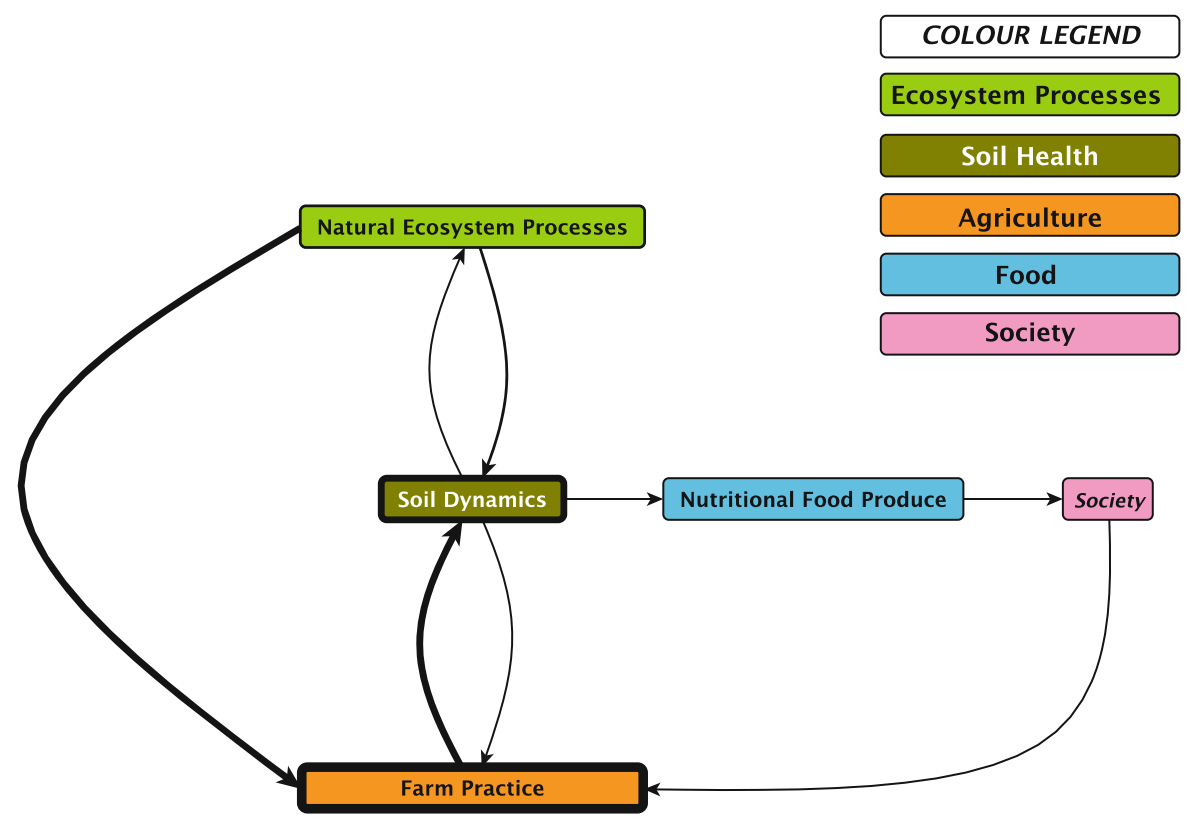

Fig. 11 Cluster simplification map: environmental, agricultural and nutritional systems. This simplified map models the key clusters in the environmental-agricultural relationship with a nutritional output perspective

system allows for organic waste in the form of biomass to be returned to the farmer, the nutrition taken from the soil by society can be returned via the farmer to the agricultural landscape to complete the cycle. In contrast, the highlighted area on Fig. 13 shows that when society allows biomass to be discharged from the system, the opportunity to replenish nutrition to the environment is diminished. In this case, the only supply of nutrients to the soil is from that provided by nature. As agriculture withdraws from this soil nutrient bank without making any deposits, we can guess that the bank of micronutrients will be depleted. Modelling will help to estimate the impact.

\section{An appropriate modelling response for nutritional cycling outcomes}

The interconnectedness of the relationship map clearly reveals a complex system, identifying linear causal chains and non-linear feedback loops. The nature of the interactions is at least as important as the individual elements themselves. The map is deliberately generic and makes no attempt to measure spatial or temporal scales. However, any modelling response will require multi-scale boundaries to be defined to assess changes to any intervention strategies implemented.

The move from a map to a model is a move from an understanding of the connectedness of functional activities to the interacting dynamics of all the relationships. In mapping the system, the focus on nutrition flows has addressed the question of what we are trying to understand. How to model this complex system could be asked in either of two ways.

1. Should the model of a system be written to incorporate these relationships from the bottomup?

or

2. Should the model of a system be written to incorporate these relationships from the topdown?

Modelling unique systems from the bottom-up

If it is implied that system control mechanisms are at the lowest levels and responsibilities for function are at the system element level (Hutchinson 2002; Crespi et al. 2008), then one modelling response is to describe the relationships on a specific landscape in order to determine system behaviour. The system map 


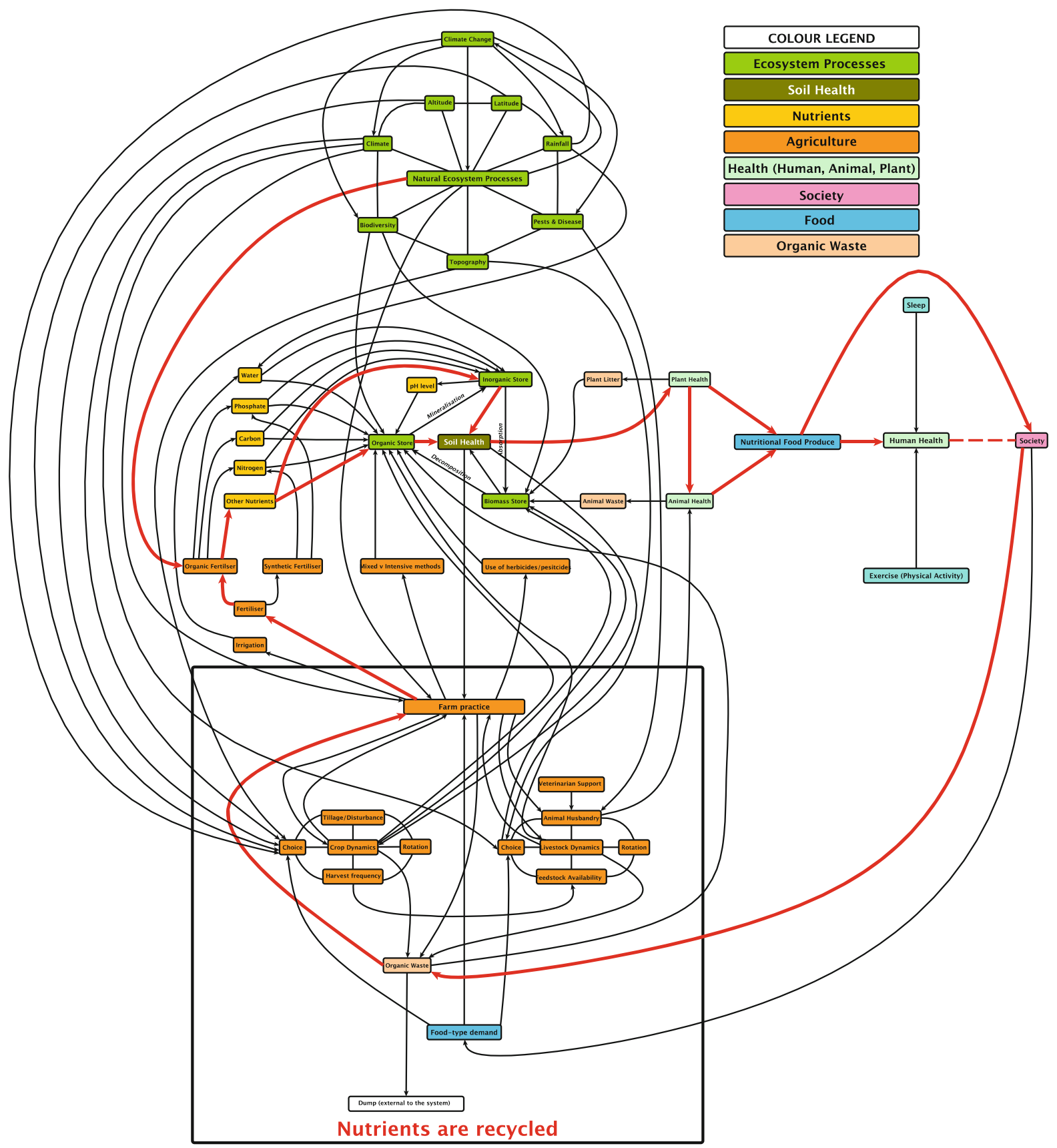

Fig. 12 Map integrating environmental, agricultural and nutritional systems, highlighting the nutrition cycle. This map highlights the key relationship flows between various elements in the environmental-agricultural relationship with a nutritional perspective

developed in "Mapping the environmental and agricultural system relationships in order to trace nutrient cycling" section above linked a conceptual agricultural and environmental system landscape, focussing on the capture of the micro-nutrient cycle. This recognises a relationship between biology, environment and social science as an opportunity to link human health to environmental health (Beauman et al. 2005; Cannon and Leitzmann 2005). Once system behaviour is understood, ex-ante assessment of 


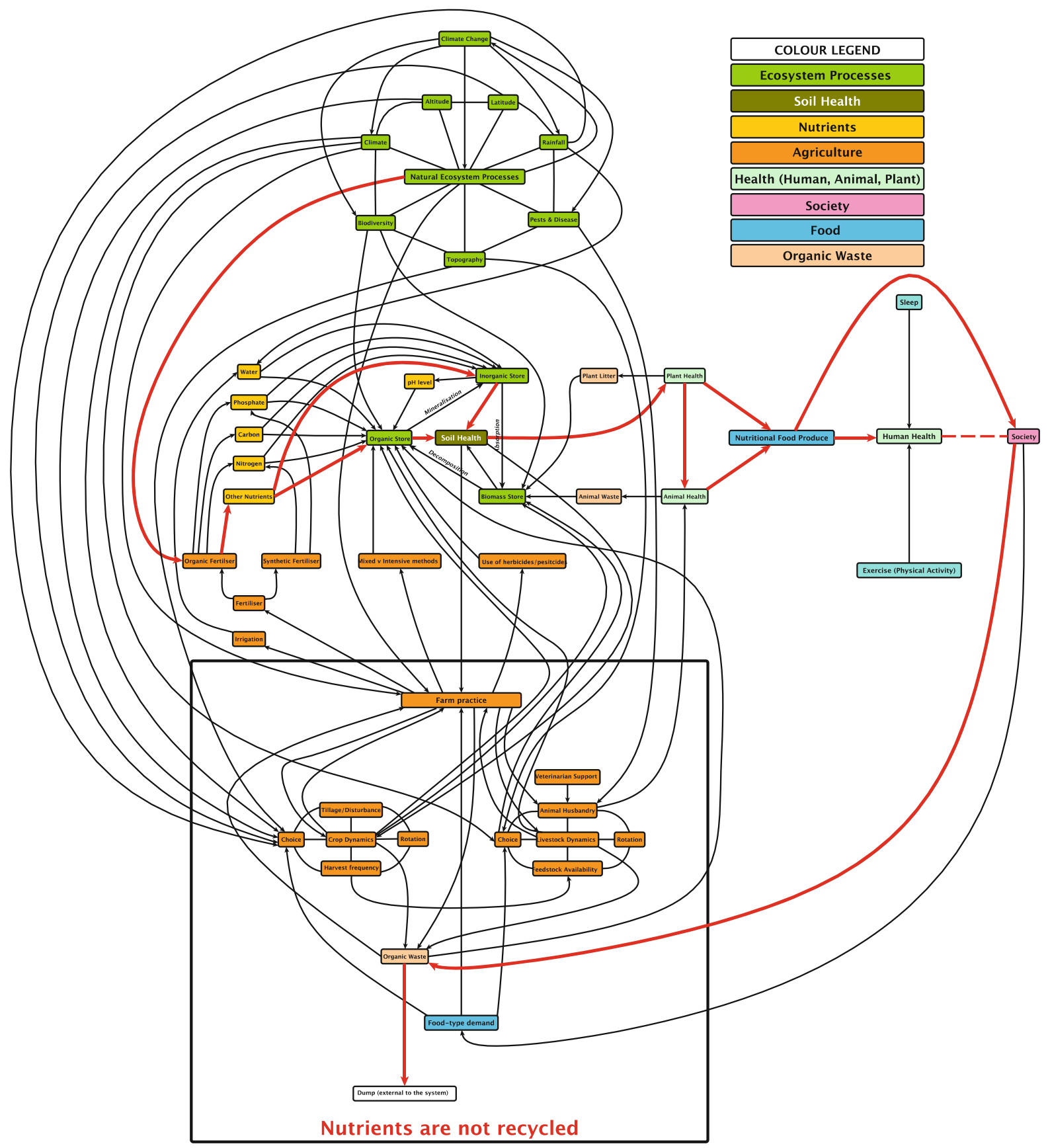

Fig. 13 Map integrating environmental, agricultural and nutritional systems, highlighting a break in the nutrition cycle. This map highlights the key relationship flows between various elements in the environmental-agricultural relationship with a

policies and interventions can be tested within the modelling framework. To build such a model, activity between components of the system are connected and nutritional perspective, but that there is a loss in the cycle of nutrients when organic waste and biomass is not recycled through the agricultural system

extended as new components are recognised and incorporated. Because it is a complex system, it will be unique and arguably, site and scenario specific. It will 
be difficult to predict system outcomes until the integrated model is created. As this system expands and the model is made operational, emergent properties of how the system behaves will be observed.

How to model a system from the bottom-up will depend on the dynamics of the system and type of interventions to be applied. Where a pathway can be identified, a system dynamics model will follow a flow of activity between elements in the system. The system map, such as that produced in "Mapping the environmental and agricultural system relationships in order to trace nutrient cycling" section above, helps to determine the boundaries of a system and the relationships between its elements.

\section{A system dynamics modelling approach}

A system dynamics model uses the language of "stocks and flows". The process begins with what should be included or excluded, how the elements to be included are represented (stocks), and how the relationships between the elements should be represented (flows) (Richmond 2004). A system dynamics modelling method naturally follows from a map of the system when the dynamic relationships are captured. A simple system dynamics model is replicated in Fig. 14. In this case, the farmer fortifies soil with iodine within the soil system with the expectation that plants will absorb the iodine in order to improve the micro-nutrition of the crop.

To introduce or adjust for an element within a system, a system dynamics model will be an appropriate response. Other examples include biological controls when the introduction of a specialist herbivore is simulated to manage invasive plants (Rughu et al. 2007), or accurate system dynamics modelling applied to agriculture to determine the impact of climate-driven production variability to balance production rates with farm capacity (Alcock 2006).

\section{An agent based modelling approach}

Another alternative modelling application is agent based modelling (ABM). ABM simulates the behaviour of complex systems over time, featuring interactions between agents leading to emergent outcomes from the explicit representation of dynamic behaviour of heterogeneous agents (Heckbert et al. 2010). Behavioural instructions are coded to agents which then act and react with each other independently. These interactions can be observed at the micro/ individual level, however at the macro-scale/system scale, patterns emerge. While each run of an ABM will be different, repetitions of certain patterns are expected to appear. When aggregated, a normal distribution of results can be captured. ABM allows the simulation to be probed with variation, such as a policy intervention. The re-run model allows for an emergent behaviour to appear. For complex systems in ecology and the nature-farming interface, $A B M$ allows for the testing and observation of virtual policy interventions ex-ante of actual funding and implementation. For example, ABM has been used to simulate the effect of earthworms on soil structure (Blanchart et al. 2009) and earthworm responses to pesticide applications (Johnston et al. 2014). In these two examples, the behaviour of the earthworms interact with their environment according to a set of rules, which apply themselves to earth structure in the first example, or as in the second example, a reaction to an intervention. They are both bottom-up approaches that allow description of a system at a micro-level in order to observe simulations and results at a macro-level.

A top-down modelling approach and the integration of existing system models

In order to capture the important interactions of complex systems holistically, a top-down modelling

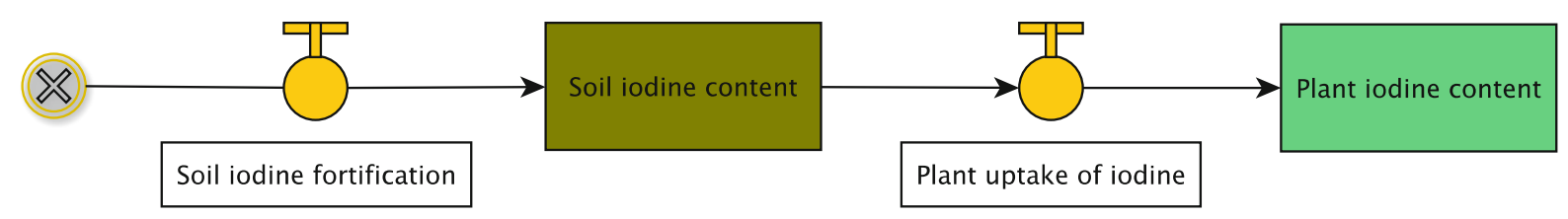

Fig. 14 Schematic of system dynamics modelling. A farmer adds iodine (I) to the soil as a micronutrient fortification process with the intent that plants will absorb the iodine to improve the nutrition of the crop 
framework is considered. This is particularly suited to conditions where the whole-of-systems specifications can be defined globally and are assumed to remain stable. Design is developed principally within a stable systems framework with the relationship between subcomponents of the system clearly described (Crespi et al. 2008). Clusters form naturally, and links between clusters and elements in those clusters are made. At the very least, top down wholeof-systems design helps to frame themes within a system before the detailed relationships are explored.

When bottom-up models are developed, by detailing the base elements of the system, these are often linked together to form larger subsystems at another scale for example, within a top-down framework. The approach to map the nutrient cycling system in "Mapping the environmental and agricultural system relationships in order to trace nutrient cycling" section was initially conceived as a top-down system design. The soil nutrient flow from nature, to agriculture, to society formed the basis of cluster construction. The assumption of a stable relationship between these clusters from a top-down approach helped to map, at a smaller scale, the activity occurring in the soil. A bottom-up approach then sought to identify connections within and between the clusters to map the complexity of the relationships.

Rather than building a model, existing legacy system models may be utilised against which data is applied to determine outcomes. Examples of legacy system models can be found from global environmental impact prediction through to farm-scale agricultural management. For environmental management, examples include General Circulation Models (Randal 2000) for climate change adjustment and models such as GARP (Anderson et al. 2003) for evaluating, predicting and optimising species distribution, and BIOCLIM (Beaumont et al. 2005) used for predicting species distributions against climatic parameters. At the farm scale, examples include the CENTURY Model for soil nutrient cycling, the Roth $\mathrm{C}$ biogeochemical cycling model for soil, the SIRIUS wheat growing simulation model, the GRASIM (Mohtar et al. 2000a) livestock grazing model, and FarmDESIGN (Groot et al. 2012a) for on farm multiobjective relationship optimisation. These models request specific parameters against which data is married to determine a response for a policy recommendation.
Standard nutritional systems models are not so easily synthesised due to the range of physiological differences, dietary choices and opportunities among individuals. Nevertheless, examples include the Geometric Framework on macro-nutritional target intake, balancing proteins, fats and carbohydrates (Simpson and Raubenheimer 2012a) and for micro-nutrition, various national food and nutrition guidelines will suggest dietary intake for minerals, such as the recommended intake of $150 \mu \mathrm{g}$ of iodine per person per day (WHO 1996; Food and Agriculture Organisation 2002). A further example can be found with the Foresight, Tackling Obesities: Future Choices Project as mentioned earlier, which sought to achieve a conceptual food system-wide framework to understand contributors to obesity (Butland et al. 2007a).

Integrating existing top-down system models to create one large model incorporating the food production system is a conceptual possibility, however for data from one model to be synthesised and included as a data input to another, algorithms need to be written to link these models. Conceptually, and with some examples from above of the many system models available, this may look like the diagram in Fig. 15.

A modelling response incorporating both a topdown and bottom-up approach

Separate scenario specific models such as some of those pieced together in Fig. 15 have been criticised for their lack of flexibility and inability to integrate with other models (Bezlepkina et al. 2014), their failure to deliver to both the farm-scale and the sector scale (Dalgaard et al. 2003), their lack of ability to give cross disciplinary meaning, their limitation to be case specific, and their inability to be used beyond the environment for which they were designed (Van Ittersum et al. 2008a). To address these shortfalls, work has been done within the European Union to create models of systems which can give both a macro and micro perspective on system behaviour and incorporate spatial and temporal impacts to allow for ex-ante assessment of policies and interventions (Podhora et al. 2013; Bezlepkina et al. 2014).

The ambitious SEAMLESS (System for Environmental and Agricultural Modelling; Linking European Science and Society) project brought together over 100 scientists from broad disciplines across 15 countries to deliver an integrated framework to support the 


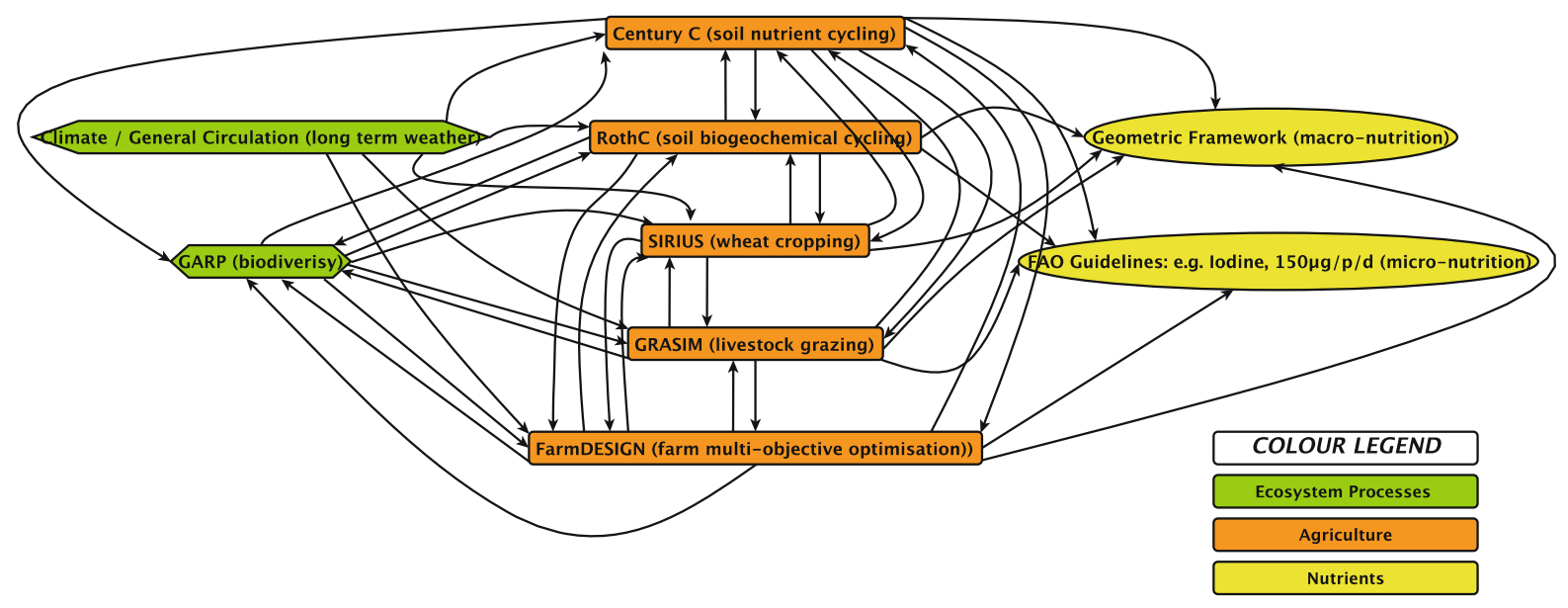

Fig. 15 Conceptual system of amalgamated models. Some relationships are linear and some have a mutual feedback system between two models. The feedback mechanisms would make

assessment of agricultural systems at multiple scales (from field, farm, region to EU and global). The model created a component-based system where each submodel can be used either as stand alone modules or integrated into a broader model for new problems. The software infrastructure supports the re-use and the linkage of the components across different landscapes and scenarios. The model capabilities provide for environmental, economic, social and institutional aspects of agricultural systems (Van Ittersum et al. 2008a).

Similarly the SENSOR (a Sustainability Impact Assessment Tool) and the DPSIR (Drivers, Pressures, State, Impacts, Response) models provide for a topdown framework seeking to resolve the conflicts and outcomes from competing land use policies by answering three questions: 1 . What kind of land use changes are to be expected as a consequence of policy intervention? 2. Where will the expected changes take place and what environmental, social and economic effects would they induce? 3 . Will the expected effects matter in terms of regional sustainable development? (Helming et al. 2011a, b).

A third example is the LIAISE (Linking Impact Assessment Instruments to Sustainable Expertise) network which supports the impact assessment process with the final goal being to support future sustainable policies and design (LIAISE 2014). This has been successfully applied to agricultural development in rural Greece (Bournaris et al. 2014). such an arrangement extremely difficult to create as different models use different non-compatible data sets

These systems and the methods used have developed a successful framework addressing issues from a holistic perspective. The LUPIS project (Land Use Policies and Sustainable Development in Developing Countries) engaged researchers from different countries, cultures and backgrounds to collaborate on the development of a common methodological framework, with modelling and assessment tools to address issues of land use problems in case studies across seven developing countries (Brazil, India, China, Indonesia, Kenya, Mali and Tunisia). The project built a knowledge bridge in the process between the two complimentary projects and methodologies of both SEAMLESS and SENSOR (Reidsma et al. 2011a; Bezlepkina et al. 2014).

Provided a realistic system of governance is incorporated (McNiell et al. 2014), projects such as SEAMLESS, SENSOR and LIAISE have demonstrated the feasibility of linking model components for use in integrated assessment in an attempt to bring together a top-down and bottom-up approach to agricultural land management. The system map developed in "Mapping the environmental and agricultural system relationships in order to trace nutrient cycling" section above was built from the bottom-up, starting with soil, but the parameters of the larger systems of environment and agriculture were conceived within top-down boundaries, building in clusters around environmental processes and farming practices with nutrition as the currency. 
As systems become complex in character, policy interventions cannot be understood at only the macro or micro level. Cross-scale consideration from one hierarchical level to another is essential as complexity increases (Dalgaard et al. 2003; van Ittersum et al. 2008). Within a top-down approach to understand an existing system, required is a framework describing both the problem and a definition of the scenario, a modelling phase that assesses the impacts of policies on multiple indicators, and a post-modelling phase assessing policy options. As part of the framework, a bottom-up modelling process allows the properties of system dynamics to emerge, enabling integration with other systems. Knowing that interventions at the micro scale have the ability to affect the entire system, the appropriate modelling approach for complex systems is to take account of both macro and micro scales.

\section{Conclusion}

A sustainable food production system is one in which activity supports a system that can inter-generationally provide adequate nutrition and energy to people, and enhance the natural environment in which it is produced. If the goal is to source nutritionally dense food using farming methods that regenerate the natural environment, then the implications of policy interventions need to be understood before they are implemented.

Complex systems are unique. Modelling of complex systems begins with the functionality of system elements. This paper has mapped the nutrient cycling process from the bottom-up, beginning with soil, expanding links to other influences to create a picture within a top-down framework to understand the interacting relationships between elements in an environmental-agricultural system. The map clearly demonstrated the complexity of the interrelated elements between farm practices and the complexity of natural ecosystem processes.

Moving from a broad conceptual system map to a generic model provides its own challenges. In complex systems nutrition-sensitive agriculture, interventions at the micro scale have the ability to affect the entire system. To be considered for bottom-up modelling, are both physical relationships; such as plant mineral absorption rates, different soil types and different geographies; and modelling structures, such as whether to model using system dynamics or ABM. Yet a whole-of-systems approach is required to capture all the detail. To address this, projects such as SEAMLESS and SENSOR are evidence of efforts to create land use policy models within a top-down framework integrating component bottom-up models, capable of being used in different scenarios. These models offer the potential to examine systems and policy interventions holistically and in detail.

Whether existing models or new scenario and sitespecific models are used, it follows that in order to achieve broad system objectives and understand the details of system interactions, the appropriate modelling approach must take account of both macro topdown and micro bottom-up scales.

Open Access This article is distributed under the terms of the Creative Commons Attribution 4.0 International License (http:// creativecommons.org/licenses/by/4.0/), which permits unrestricted use, distribution, and reproduction in any medium, provided you give appropriate credit to the original author(s) and the source, provide a link to the Creative Commons license, and indicate if changes were made.

\section{References}

Adams CA (2006) Nutrition-based health in animal production. Nutr Res Rev 19(1):79-89. doi:10.1079/NRR2005115

Alcock DJ (2006) Using grazing systems modelling to assess economic, production and environmental risks to aid in selecting appropriate stocking rates. Aust J Exp Agric 46:841-844. doi:10.1071/EA05302

Alemseged Y, Hacker RB, Smith WJ, Melville GJ (2011) Temporary cropping in semi-arid shrublands increases native perennial grasses. Rangel J 33(1):67-78. doi:10. 1071/RJ10022-1036-9872/11/010067

Allen CR, Gunderson L, Johnson AR (2005) The use of discontinuities and functional groups to assess relative resilience in complex systems. Ecosystems 8(8):958-966. doi:10.1007/s10021-005-0147-x

Allen T, Prosperi P, Cogill B, Flichman G (2014) Agricultural biodiversity, social-ecological systems and sustainable diets, conference on "Sustainable diet and food security" symposium 2: food production system. Proc Nutr Soc 73:498-508. doi:10.1017/S002966511400069X

Anderson RP, Lew D, Peterson AT (2003) Evaluating predictive model of species' distributions: criteria for selecting optimal models. Ecol Model 162:211-232

Ball BC, Bingham I, Rees RM, Watson CA, Litterick A (2005) The role of crop rotations in determining soil structure and crop growth conditions. Can J Soil Sci 85(5):557-577. ISSN: 0008-4271

Bardgett RD, Freeman C, Ostle NJ (2008) Microbial contributions to climate change through carbon cycle feedbacks. ISME J 2(8):805-814. doi:10.1038/ismej.2008.58 
Bardgett RD, McAlister E (1999) The measurement of soil fungal/bacterial biomass ratios as an indicator of ecosystem self-regulation in temperate meadow grasslands. Biol Fertil Soils 29(3):282-290. doi:10.1007/s0037400505554

Beauman C, Cannon G, Elmadfa I, Glasauer P, Hoffmann I, Keller M, Krawinkel M, Lang T, Leitzmann C, Lotsch B, Margetts BM, McMichael AJ, Meyer-Abich K, Oltersdorf U, Pettoello-Mantovani M, Sabate J, Shetty P, Soria M, Spiekermann U, Tudge C, Vorster HH, Wahlqvist M, Zerilli-Marimo M (2005) The principles, definitions and dimensions of the new nutrition science. Public Health Nutr 8(6A):695-698. doi:10.1079/PHN2005820

Beaumont LJ, Hughes L, Poulsen M (2005) Predicting species distributions: use of climatic parameters BIOCLIM and its impact on predictions of species' current and future distributions. Ecol Model 186:250-269. doi:10.1016/j. ecolmodel.2005.01.030

Beddington J (2010) Food security: contributions for science to a new and greener revolution. Philos Trans R Soc 365:61-71. doi:10.1098/rstb.2009.0201

Bezlepkina I, Brouwer F, Reidsma P (2014) Impact assessment of land use policies: introduction. Land Use Policy 37:1-5. doi:10.1016/j.landusepol.2013.03.010

Blanchart E, Marilleau N, Chotte J-J, Drogoul A, Perrier E, Cambier Ch (2009) SWORM: an agent-based model to simulate the effect of earthworms on soil structure. Eur J Soil Sci 60:13-21. doi:10.1111/j.1365-2389.2008.01091.x

Bontkes TS, van Keulen H (2003) Modelling the dynamics of agricultural development at farm and regional level. Agric Syst 76(1):376-396. doi:10.1016/S0308-521X(02)00128-2

Bouis HE (2002) Plant breeding: a new tool for fighting micronutrient malnutrition. J Nutr 132:491S-494S. ISSN: 0022-3166

Bournaris T, Moulogianni C, Manos B (2014) A multicriteria model for the assessment of rural development plans in Greece. Land Use Policy 38:1-8. doi:10.1016/j.landusepol. 2013.10.008

Brown MJF, Paxton RJ (2009) The conservation of bees: a global perspective. Apidologie 40(3):410-416. doi:10. 1051/apido/2009019

Bunemann EK, Schwenke GD, Van Zqieten L (2006) Impact of agricultural inputs on soil organisms. Aust J Soil Res 44:379-406. doi:10.1071/SR05125-0004-9573/06/040379

Burdock RP, Crawford J (2012) The challenge to modelling system interdependency across the natural environment and agriculture. Manag Environ Quality Int J 23(5):527-535. doi:10.1108/14777831211255105

Butland B, Jebb S, Kopelman P, McPherson K, Thomas S, Mardel J, Parry V (2007) Foresight, tackling obesities: future choices-project report, 2nd edn. Government Office for Science, UK. DIUS/PUB 8654/2K/12/07/AR

Butzer KW, Endfield GH (2012) Critical perspectives on historical collapse. Proc Natl Acad Sci 109(10):3628-3631. doi:10.1073/pnas.1114772109

Byron AB, Baghurst K, Cobiac L, Baghurst P, Magarey A (2011) A modelling system to inform the revision of the Australian guide to healthy eating, Australian Government, Department of Health and Ageing, National Health and Medical Research Council, Commonwealth of Australia, Canberra, Australia, in conjunction with Dietitians
Association of Australia, IBSN Online 1864965398. www. nhmrc.gov.au

Campbell WC, Conder GA, Marchiondo AA (2009) Future of the animal health industry at a time of food crisis. Vet Parasitol 163(3):188-195. doi:10.1016/j.vetpar.2009.05.025

Cannon G, Leitzmann C (2005) The new nutrition science project. Public Health Nutr 8:673-694. doi:10.1079/ PHN2005819

Choi TY, Dooley KJ, Rungtusanatham M (2001) Supply networks and complex adaptive systems: control versus emergence. J Oper Manag 19(3):351-366. doi:10.1016/ S0272-6963(00)00068-1

Clyde RG, Bown JL, Hupp TR, Zhelev N, Crawford JW (2006) The role of modelling identifying drug targets for diseases of the cell cycle. J R Soc Interface 3:617-627. doi:10.1098/ rsif.2006.0146

Cordain L, Eaton SB, Sebastian A, Mann N, Lindeberg S, Watkins BA, O'Keefe JH, Brand-Miller J (2005) Origins and evolution of the Western diet: health implications for the 21st century. Am J Clin Nutr 81(2):341-354. ISSN: $0002-9165$

Crespi V, Galstyan A, Lerman K (2008) Top-down vs bottomup methodologies in multi-agent system design. Auton Robot 4(3):303-313. doi:10.1007/s10514-007-9080-5

Dalgaard T, Hutchings NJ, Porter JR (2003) Agroecology, scaling and interdisciplinarity. Agric Ecosyst Environ 100(1):39-51. doi:10.1016/S0167-8809(03)00152-X

Dangour AD, Green R, Hasler B, Rushton J, Shankar B, Waage J (2012) Linking agriculture and health in low- and middleincome countries: an interdisciplinary research agenda. Proc Nutr Soc 71(2):222-228. doi:10.1017/S0029665112000213

Davis RD (2009) Declining fruit and vegetable nutrient composition: What is the evidence? Hortic Sci 44(1):15-19. ISSN: 0018-5345

Davis RD, Epp MD, Riordan HD (2004) Changes in USDA food composition data for 43 garden crops, 1950 to 1999. J Am Coll Nutr 23(6):669-682. ISSN: 0731-5724

de Nooy W, Mrvar A, Batageli V (2005) Exploratory social network analysis with Pajek. Cambridge University Press, Cambridge. ISBN: 978-0-521-84173-3

Deffuant G, Gilbert N (2011) Viability and resilience of complex systems: concepts, methods and case studies from ecology and society (understanding complex systems). Springer, Berlin. ISBN: 978-3-642-20422-7

Dogliotti S, Giller KE, Van Ittersum MK (2014) Achieving global food security whilst reconciling demands on the environment: report of the first international conference on global food security. Food Secur 6:299-302. doi:10.1007/ s12571-014-0334-8

Doney SC, Ruckelshaus M, Duffy JE, Barry JP, Chan F, English CA, Galindo HM, Grebmeier JM, Hollowed AB, Knowlton N, Polovina J, Rabalais NN, Sydeman WJ, Talley LD (2012) Climate change impacts on Marine ecosystems. Annu Rev Mar Sci 4:11-37. doi:10.1146/annurev-marine041911-111611

Doughty CE, Wolf A, Malhi Y (2013) The legacy of the Pleistocene megafauna extinctions on nutrient availability in Amazonia. Nat Geosci. doi:10.1038/NGEO1895

Drinkwater KF, Beaugrand G, Kaeriyama M, Kim S, Ottersen G, Perri RI, Portner HO, Polovina JJ, Takasuka A (2010) 
On the processes linking climate to ecosystem changes. J Mar Syst 79:374-388. doi:10.1016/j.marsys.2008.12.014 Esrey SA (2001) Towards a recycling society: ecological sanitation-closing the loop to food security. Sci Technol 43(4):177-187. ISSN: 0273-1223

Faratian D, Clyde RG, Crawford JW, Harrison DJ (2009) System pathology - taking molecular pathology into a new dimension. Nat Rev Clin Oncol 6:455-464. doi:10.1038/ nrclinonc.2009.102

Finegood DT, Merth TDN, Rutter H (2010) Implication of the foresight obesity system map for solutions to childhood obesity. Obes J 18(S1):S13-S16. doi:10.1038/oby.2009.426

Furst T, Connors M, Bisogni CA, Sobal J, Falk LW (1996) Food choice: a conceptual model of the process. Appetite 26(3):247-266. doi:10.1006/appe.1996.0019

Fynn RP, Roller WL, Keener HM (1989) A decision-model for nutrition management in controlled environment agriculture. Agric Syst 31(1):35-53. doi:10.1016/0308-521X(89)90011-5

Geissler CA, Powers HJ (2005) Human nutrition. Elsevier/ Churchill Livingstone, Edinburgh. ISBN: 978-0443073564

Geist HJ, Lambin EF (2004) Dynamic causal patterns of desertification. Bioscience 54(9):817-829. doi:10.1641/ 0006-3568(2004)054[0817:DCPOD]2.0.CO;2

Godfray HCJ, Beddington JR, Crute IR, Haddad L, Lawrence D, Muir JF, Pretty J, Robinson S, Thomas SM, Toulmin C (2010) Food security: the challenge of feeding 9 billion people. Science 327:812-818. doi:10.1126/science.1185383

Gooding MJ, Fan MS, McGrath SP, Shewry PR, Zhao FJ (2012) Contrasting effects of dwarfing alleles and nitrogen availability on mineral concentrations in wheat grain. Plant Soil 360:93-107. doi:10.1007/s11104-012-1203-x

Govaerts B, Mezzalama M, Unno Y, Sayre KD, Luna-Guido M, Vanherck K, Dendooven L, Deckers J (2007) Influence of tillage, residue management and crop rotation on soil microbial biomass and catabolic diversity. Appl Soil Ecol 37:18-30

Gray SB, Classen AT, Kardol P, Yermakov Z, Miller RM (2011) Multiple climate change factors interact to alter soil microbial community structure in an old-field ecosystem. Soil Sci Soc Am J 75(6):2217-2226. doi:10.2136/ sssaj2011.0135

Groot JCJ, Oomen GJM, Rossing WAH (2012a) Multiobjective optimization and design of farming systems. Agric Syst 110:63-77. doi:10.1016/jagsy.2012.03.012

Grusak MA, DellaPenna D (1999) Improving the nutrient composition of plants to enhance human nutrition and health. Annu Rev Plant Physiol Plant Mol Biol 50:133-161. doi:10.1146/annurev.arplant.50.1.133

Gupta UC, Wu KN, Liang SY (2008) Micronutrients in soils. Crops Livest Earth Sci Front 15(5):110-125

Haimes YY (2009) On the complex definition of risk: a systemsbased approach. Risk Anal 29(12):1647-1654. doi:10. 1111/j.1539-6924.2009.01310.x

Halson SL (2008) Nutrition, sleep and recovery. Eur J Sport Sci 8(2):119-126. doi:10.1080/17461390801954794

Halweil B (2007) Still no free lunch: nutrient levels in U.S. food supply eroded by pursuit of high yields, The Organic Center Critical Issue Report. http://organic.insightd.net/ reportfiles/Yield_Nutrient_Density_Final.pdf. Accessed 24 Dec 2014
Harris KM, King RB, Gordon-Larsen P (2005) Healthy habits among adolescents: sleep, exercise, diet and body image. In: Lippman L, Moore K (eds) Conceptulalizing and measuring indicators of positive development: What do children need to flourish?. Springer, New York, pp 111-132. ISBN: 978-0387230610

Heckbert S, Baynes T, Reeson A (2010) Agent-based modelling in ecological economics. Ann NY Acad Sci Ecol Econ Rev 1185:39-53. doi:10.1111/j.1749-6632.2009.05286.x

Helfrich M, Ludwig B, Potthoff M, Flessa H (2008) Effect of litter quality and soil fungi on macroaggregate dynamics and associated partitioning of litter carbon and nitrogen. Soil Biol Biochem 40(7):1823-1835. doi:10.1016/j. soilbio.2008.03.006

Helming K, Diehl K, Bach H, Dilly O, Konig B, Kuhlman T, PerezSoba M, Sieber S, Tabbush P, Tscherning K, Wascher D, Wiggering H (2011) Ex ante impact assessment of policies affecting land use. Part A. Analytical framework. Ecol Soc 16(1):C7-C27. http://www.ecologyandsociety.org/vol16/iss1/ art27/

Helming K, Diehl K, Kuhlman T, Jansson T, Verburg PH, Bakker M, Perez-Soba M, Jones L, Johannes Verkerk T, Tabbush P, Breton Morris J, Drillet Z, Farrington J, LeMouel P, Zagame P, Stuczynski T, Siebielec G, Wiggering H (2011) Ex ante impact assessment of policies affecting land use. Part B. Application of the Analytical framework. Ecol Soc 16(1). http://www.ecologyandsociety.org/vol16/iss1/art29/

Hobbs RJ, Norton DA (1996) Towards a conceptual framework for restoration ecology. Restor Ecol 4(2):93-110. doi:10. 1111/j.1526-100X.1996.tb00112.x

Hodgson JM, Hsuhage BHH, Wahlqvist ML (1994) Food variety as a quantitative descriptor of good food-intake. Ecol Food Nutr 32(3-4):137-148. doi:10.1080/03670244. 1994.9991395

Holland JM (2004) Environmental consequences of adopting conservation tillage in Europe: reviewing the evidence. Agric Ecosyst Environ 103(1):1-25. doi:10.1016/j.agee. 2003.12.018

Hughes CL, Dhiman TR (2002) Dietary compounds in relation to dietary diversity and human health. J Med Food 5(2):51-68. http://online.liebertpub.com/toc/jmf/5/2

Hutchinson W (2002) Bottom up thinking in Part 8, development \& applications of systems methodology. In: Synergy matters: working with systems in the 21 st century. Springer, Berlin, pp 445-450. ISBN: 978-0306461866

Ingram J (2011) A food systems approach to researching food security and its interactions with global environmental change. Food Secur 3(4):417-431. doi:10.1007/s12571011-0149-9

Johnston ASA, Hodson ME, Thorbek P, Alvarez T, Sibly RM (2014) An energy budget agent-based model of earthworm populations and its application to study the effects of pesticides. Ecol Model 280(SI):5-17. doi:10.1016/j. ecolmodel.2013.09.012

Kaine GW, Tozer PR (2005) Stability, resilience and sustainability in pasture-based grazing systems. Agric Syst 83(1):27-48

Keding GB, Schneider K, Jordan I (2013) Production and processing of foods as core aspects of nutrition-sensitive agriculture and sustainable diets. Food Secur 5(6):825-846. doi:10.1007/s12571-013-0312-6 
Knutson KL, Spiegel K, Penev P, Van Cauter E (2007) The metabolic consequences of sleep deprivation. Sleep Med Rev 11(3):163-178. doi:10.1016/j.smrv.2007.01.002

Kremen C, Williams NM, Thorp RW (2002) Crop pollination from native bees at risk from agricultural intensification. Proc Natl Acad Sci USA 99(26):16812-16816. doi:10. 1073/pnas.262413599

Kurtz CF, Snowden DJ (2003) The new dynamics of strategy: sense-making in a complex and complicated world. IBM Syst J 42(3):462-483. ISSN: 0018-8670

Lai R (2009) Soil degradation as a reason for inadequate human nutrition. Food Secur 1(1):45-57. doi:10.1007/s12571009-0009-z

Larsen CS (2003) Animal source foods and human health during evolution. J Nutr 133((11) Supplement 2):3893S-3897S. ISSN: 0022-3166

Lensing JR, Wise DH (2006) Predicted climate change alters the indirect effect of predators on an ecosystem process. Proc Natl Acad Sci USA 103(42):15502-15505. doi:10.1073/ pnas.0607064103

Liu YY, Soltine JJ, Barabasi AL (2011) Controllability of complex networks. Nature 473:167-173. doi:10.1038/ nature 10011

Maani KE, Maharaj V (2004) Links between systems thinking and complex decision making. Syst Dyn Rev 20(1):21-48. doi:10.1002/sdr.281

Marschner P, Rengel Z (2007) Nutrient cycling in terrestrial ecosystems (soil biology). Springer, Berlin. ISBN: 978-3540-68026-0

Mayer AM (1997) Historical changes in the mineral content of fruits and vegetables. Br Food J 99(6):207-211. doi:10. 1108/00070709710181540

McNiell D, Bursztyn M, Novira N, Purushothaman S, Verburg R, Rodrigues-Filho S (2014) Taking account of governance: the challenge for land-use planning models. Land Use Policy 37:6-13. doi:10.1016/j.andusepol.2012.09.006

Mediene S, Valantin-Morison M, Sarthou JP, de Tourdonnet S, Gosme M, Bertrand M, Roger-Estrade J, Aubertot JN, Rusch A, Motisi N, Pelosi C, Dore T (2011) Agroecosystem management and biotic interactions: a review. Agron Sustain Dev 31(3):491-514. doi:10.1007/s13593-011-0009-1

Mertz W (1994) A balanced approach to nutrition for health: the need for biologically essential minerals and vitamins. J Am Diet Assoc 94(11):1259-1262. doi:10.106/00028223(94)92456-2

Michels KB, Wolk A (2002) A prospective study of variety of healthy foods and mortality in women. Int $\mathrm{J}$ Epidemiol 31(4):847-854. doi:10.1093/ije/31.4.847

Mignot E (2008) Why we sleep: the temporal organisation of recovery, PLoS (Public Library of Science). Biology. doi:10.1371/journal.pbio.0060106

Morris CE, Sands DC (2006) The breeder's dilemma-yield or nutrition? Nat Biotechnol 24:1078-1080. doi:10.1038/ nbt0906-1078

Mohtar RH, Zhai T, Chen XW (2000a) A world wide web-based grazing simulation model (GRASIM). Comput Electron Agric 29(3):243-250. doi:10.1016/S0168-1699(00)00147-2

Nielsen UN, Ayres E, Wall DH, Bardgett RD (2011) Soil biodiversity and carbon cycling: a review and synthesis of studies examining diversity-function relationships. Eur J
Soil Sci 62(1):105-116. doi:10.1111/j/1365-2389.2010. 0314.x

Norris C, Hobson P, Ibisch PL (2012) Microclimate and vegetation function as indicators of forest thermodynamic efficiency. J Appl Ecol 49(3):563-570. doi:10.111/j.13652664.2011.02084.x

Parrott L (2010) Measuring ecological complexity. Ecol Ind 10:1069-1076. doi:10.1016/j.ecolind.2010.03.014

Penders B, Horstman K, Vos R (2009) Large-scale research and goal of health: doable problem construction in "New" nutrition science. Interdisc Sci Rev 34(4):327-344. doi:10. 1179/030801809X12529269201200

Penedo FJ, Dahn JR (2005) Exercise and well-being: a review of mental and physical health benefits associated with physical activity. Curr Opin Psychiatry 18(2):189-193. doi:10. 1097/00001504-200503000-00013

Pfister F, Bader HP, Scheidegger R, Baccini P (2005) Dynamic modelling of resource management for farming systems. Agric Syst 86(1):1-28. doi:10.1016/j.agsy.2004.08.001

Pimentel D (2006) Soil erosion: a food and environmental threat. Environ Dev Sustain 8:119-137. doi:10.1007/ s10668-005-1262-8

Podhora A, Helming K, Adenauer L, Heckelei T, Kautto P, Reidsma P, Rennings K, Turnpenny J, Jansen J (2013) The policy-relevancy of impact assessment tools: evaluating nine years of European research funding. Environ Sci Policy 31:85-95. doi:10.1016/j.envsci.2013.03.002

Porporato A, Daly E, Rodriguez-Iturbe I (2004) Soil water balance and ecosystem response to climate change. Am Nat 164(5):625-632. doi:10.1086/424970

Poulson CS, Dhiman TR, Ure AL, Cornforth D, Olson KC (2004) Conjugated linoleic acid content of beef from cattle fed diets containing high grain, CLA, or raised on forages. Livest Prod Sci 91:117-128. doi:10.1016/j.livprodsci.2004.07.012

Powlson DS, Gregory PJ, Whalley WR, Quinton JN, Hopkins DW, Whitmore AP, Hirsch PR, Goulding KWT (2011) Soil management in relation to sustainable agriculture and ecosystem services. Food Policy 36(Supplement 1):S72S87. doi:10.1016/j.foodpol.2010.11.025

Powlson DS, Hirsch PR, Brookes PC (2000) The role of soil microorganisms in soil organic matter conservation in the tropics. Nutr Cycl Agroecosyst 61:41-51. doi:10.1023/A: 1013338028454

Randal DA (2000) General circulation model development; past present and future, international geophysics series, 70. Academic Press, San Diego, CA, USA. ISBN: 0-125780010-9

Refsgaard K, Magnussen K (2009) Household behavior and attitudes with respect to recycling food waste-experiences from focus groups. J Environ Manag 90(2):760-771. doi:10.1016/j.jenvman.2008.01.018

Reidsma P, Konig H, Feng SY, Bezlepkina I, Nesheim I, Bonin M, Sghaier M, Purushothaman S, Sieber S, van Ittersum MK, Brouwer F (2011a) Methods and tools for integrated assessment of land use policies for sustainable development in developing countries. Land Use Policy 28(3):604-617. doi:10.1016/j.landusepol.2010.11.009

Resnick HE, Carter EA, Aloia M, Phillips B (2006) Cross-sectional relationship of reported fatigue to obesity, diet, and physical activity: results from the third national health and 
nutrition examination survey. $\mathrm{J}$ Clin Sleep Med 15(2):163-169

Richmond B (2004) Stella Software, Chapter 1, systems thinking and the STELLA software, ISEE Systems. ISBN: 0-9704921-1-1. accessed from www.iseesystems.com on 18 Dec 2014

Rigby D, Caceres D (2001) Organic farming and the sustainability of agricultural systems. Agric Syst 68:21-40. doi:10.1016/S0308-521X(00)00060-3

Rughu S, Dhileepan K, Scanlan JC (2007) Predicting risk and benefit a priori in biological control of invasive plant species: a systems modelling approach. Ecol Model 208(2-4):247-262. doi:10.1016/j.ecolmodel.2007.05.022

Russell BD, Harley CDG, Wernberg T, Mieszkowska N, Widdicombe S, Hall-Spencer JM, Connell SD (2012) Predicting ecosystem shifts requires new approaches that integrate the effects of climate change across entire systems. Biol Lett 8(2):164-166. doi:10.1098/rsbl.2011.0779

Sauer T, Havilik P, Schneider UA, Schmid E, Kindermann G, Obersteiner M (2010) Agriculture and resource availability in a changing world: the role of irrigation. Water Resour Res 46:1-12. doi:10.1029/2009WR007729

Schneider ED, Kay JJ (1994) Life as a manifestation of the 2nd law of thermodynamics. Math Comput Model 19(6-8):25-48. doi:10.1016/0895-7177(94)90188-0

Schultz R, Romheld V (1997) Recycling of municipal and industrial organic wastes in agriculture: benefits, limitations, and means of improvement (Reprinted from Plant nutrition for sustainable food production and environment, 1997). Soil Sci Plant Nutr 43(1):1051-1056. ISSN: 0038-0768

Slimani H, Aidoud A, Rose F (2010) 30 years of protection and monitoring of a steppic rangeland undergoing desertification. J Arid Environ 74(6):685-691. doi:10.1016/j. jaridenv.2009.10.015

Simpson SJ, Raubenheimer D (2012a) The nature of nutrition: a unifying framework for animal adaption to human obesity. Princeton University Press, Woodstock. ISBN: 9781400842803

Sobal J, Khan LK, Bisogni C (1998) A conceptual model of the food and nutrition system. Soc Sci Med 47(7):853-863. doi:10.1016/S0277-9536(98)00104-X

St Clair SB, Lynch JP (2010) The opening of Pandora's Box: climate change impacts on soil fertility and crop nutrition in developing countries. Plant Soil 335(1-2):101-115. doi:10.1007/s11104-010-0328-z

Stentiford GD, Neil DM, Peeler EJ, Shields JD, Small HJ, Flegal TW, Vlak JM, Jones B, Morado F, Moss S, Lotz J, Bartholomay L, Behrigner DC, Hauton C, Lightner DV (2012) Disease will limit future food supply from the global crustacean fishery and aquaculture sectors. J Invertebr Pathol 110(2):141-157

Swain DP, Franklin BA (2006) Comparison of cardioprotective benefits of vigorous verses moderate intensity aerobic exercise. Am J Cardiol 97(1):141-147. doi:10.1016/j. amjcard.2005.07.130

Tanji JL (2000) The benefits of exercise for women. Clin Sports Med 19(2):175-185. doi:10.1016/S0278-5919(05)70197-6

Tucker KL (2001) Eat a variety of healthy foods: old advice with new support. Nutr Rev 59(5):156-158
Van Ittersum MK, Ewert F, Heckelei T, Wery J, Alkan Olsson J, Andersen E, Bezlepkina I, Brouwer F, Donatelli M, Flichman G, Olsson L, Rizzoli AE, van der Wal T, Wien JE, Wolf J (2008a) Integrated assessment of agricultural systems - a component-based framework for the European Union (SEAMLESS). Agric Syst 96(1-3):150-165. doi:10.1016/j.agsy.2007.07.009

Villalba JJ, Provenza FD, Manteca X (2010) Links between ruminants' food preference and their welfare. Animal 4(7):1240-1247. doi:10.1017/S1751731110000467

Vitousek PM, Naylor R, Crews T, David MB, Drinkwater LE, Holland E, Johnes PJ, Katzenberger J, Martinelli LA, Matson PA, Nziguheba G, Ojima D, Palm CA, Robertson GP, Sanchez PA, Townsend AR, Zhang FS (2009) Nutrient imbalances in agricultural development. Science 324:1519-1520

Wahlqvist ML (2004) Requirements for healthy nutrition: integrating food sustainability, food variety and health. J Food Sci 69(1):CHR16-CHR18

Wallenstein MD, Hall EK (2012) A trait-based framework for predicting when and where microbial adaption to climate change will affect ecosystem functioning. Biogeochemistry 109:35-47. doi:10.1007/s10533-011-9641-8

Watson CA, Atkinson D, Gosling P, Jackson LR, Rayns FW (2002) Managing soil fertility in organic farming systems. Soil Use Manag 18(s):239-247. doi:10.1079/SUM2002131

Welch RM, Graham RD (2004) Breeding for micronutrients in staple food crops from a human nutrition perspective. J Exp Biol 55(396):353-364. doi:10.1093/jxb/erh064

White PJ, Brown PH (2010) Plant nutrition for sustainable development and global health. Ann Bot 105:1073-1080. doi:10.1093/aob/mcq085

Zhou ZY, Li FR, Chen SK, Zhang HR, Li GD (2011) Dynamics of vegetation and soil carbon and nitrogen accumulation over 26 years under controlled grazing in a desert shrubland. Plant Soil 341:257-268. doi:10.1007/s11104-0100641-6

Zhu YG (2009) Soil science in the understanding of the security of food systems for health. Asia Pac J Clin Nutr 18(4):516-519. ISSN: 0964-7058

\section{Government cited publications}

FAO (2002) Human vitamin and mineral requirements, training materials for agricultural planning, Chapter 12, accessed at http://www.fao.org/docrep/004/y2809e/y2809e0i.htm\#bm 18.5 on 18 Dec 2014

FAO (2012) Statistical year book 2012, World Food and Agriculture, Part 4, Water. Accessed from http://www.fao.org/ docrep/015/i2490e/i2490e04b.pdf on 17 Dec 2014

FAO (2013) Food wastage footprint: impacts on natural resources. ISBN: 978-92-5-107752-8. Accessed at http:// www.fao.org/docrep/018/i3347e/i3347e.pdf 11 Dec 2013

UN (2009) UN-water annual report 2009, accessed at http:// www.unwater.org/downloads/UN-Water_Annual_Report_ 2009.pdf on 8 Dec 2014

WHO (1996) Trace elements in human nutrition and health. WHO, Geneva. ISBN: 924156173 4. Accessed at http:// whqlibdoc.who.int/publications/1996/9241561734_eng_ fulltext.pdf on 28 Nov 2014 
WHO (2004) Vitamin and mineral requirements in human nutrition, 2nd edn, Sun Fung, China. ISBN: 9241546123

WHO (2012) Nutrition challenges. http://www.who.int/ nutrition/challenges/en/. Accessed 22 Dec 2014

Cited environmental, agricultural and nutritional models

BIOCLIM: Beaumont LJ, Hughes L, Poulsen M (2005) Predicting species distributions: use of climatic parameters BIOCLIM and its impact on predictions of species' current and future distributions. Ecol Model 186:250-269. doi:10. 1016/j.ecolmodel.2005.01.030

CENTURY: A general model of plant-soil nutrient cycling which is being used to simulate carbon and nutrient dynamics for different types of ecosystems including grasslands, agricultural lands, forests and savannah. The primary purposes of the model are to provide a tool for ecosystem analysis, to test the consistency of data and to evaluate the effect of changes in management and climate on ecosystems. http://www.nrel.colostate.edu/projects/ century/accessed 24 Nov 2014

FarmDESIGN: A model developed in The Netherlands to overcome the problems of several interrelationships at the farm scale to create a multi-objective optimisation algorithm for decision making

Groot JCJ, Oomen GJM, Rossing WAH (2012b) Multiobjective optimization and design of farming systems. Agric Syst 110:63-77. doi:10.1016/jagsy.2012.03.012

Foresight, Tackling Obesities: Future Choices. A conceptual framework for understanding the interactions of the food system, physical exercise, attitudes to food consumption and human physiology

Butland B, Jebb S, Kopelman P, McPherson K, Thomas S, Mardel J, Parry V (2007) Foresight, tackling obesities: future choices-project report, 2nd edn. Government Office for Science, UK. DIUS/PUB 8654/2K/12/07/AR

GARP: Anderson RP, Lew D, Peterson AT (2003) Evaluating predictive model of species' distributions: criteria for selecting optimal models. Ecol Model 162:211-232

General Circulation Models: Randal DA (2000) General circulation model development; past present and future, international geophysics series, 70. Academic Press, San Diego, California, USA. ISBN: 0-12-5780010-9

Geometric Framework: Uses a nutrient space to determine the optimal natural balance of protein to non-protein dietary intake for long term health

Simpson SJ, Raubenheimer D (2012b) The nature of nutrition: a unifying framework for animal adaption to human obesity. Princeton University Press, Woodstock. ISBN: 9781400842803

GRASIM: Multi-paddock grazing and scheduling software with a Web interface which estimates daily forage dry matter, daily soil water content and drainage, and daily soil nitrate content and leaching for livestock management

Mohtar RH, Zhai T, Chen XW (2000b) A world wide web-based grazing simulation model (GRASIM). Comput Electron Agric 29(3):243-250. doi:10.1016/S0168-1699(00)00147-2
IPCC Models. The International Panel on Climate Change (IPCC) is the leading international body for the assessment of climate change, established by the United Nations Environment Program. http://www.ipcc.ch. Accessed 24 Nov 2014

LIAISE: The LIAISE Charter lays out a vision on how to achieve the goal of a broad, open and inclusive centre of excellence on Impact Assessment for Sustainable Development. http://www.liaise-kit.eu/. Accessed 17 Dec 2014

LUPIS: The LUPIS project (Land Use Policies and Sustainable development in Developing Countries) developed integrated assessment tools for sustainable development for application by scientists in a selected number of developing countries, and the tools developed in the EU 6th framework projects of SENSOR and SEAMLESS will be used both as building blocks in and guidelines for the project

Reidsma P, Konig H, Feng SY, Bezlepkina I, Nesheim I, Bonin M, Sghaier M, Purushothaman S, Sieber S, van Ittersum MK, Brouwer F (2011) Methods and tools for integrated assessment of land use policies for sustainable development in developing countries. Land Use Policy 28(3):604-617. doi:10.1016/j.landusepol.2010.11.009. http://www.liaise-kit.eu/practice/lupis. Accessed 17 Dec 2014

Roth C. A biogeochemical cycling model for soil accessed at http://www.rothamsted.ac.uk/sites/default/files/users/kcol eman/RothC_guide_WIN.pdf on 24 Dec 2014

SEAMLESS: European Union agricultural systems impact assessment project

Van Ittersum MK, Ewert F, Heckelei T, Wery J, Alkan Olsson J, Andersen E, Bezlepkina I, Brouwer F, Donatelli M, Flichman G, Olsson L, Rizzoli AE, van der Wal T, Wien JE, Wolf J (2008b) Integrated assessment of agricultural systems-a component-based framework for the European Union (SEAMLESS). Agric Syst 96(1-3):150-165. doi:10.1016/j.agsy.2007.07.009

SENSOR: European Union land use impact assessment project

Diehl K, König B, Helming K, Wascher D eds (2009) Tools for impact assessment: project summary, IP SENSOR. Leibniz-Centre for Agricultural Landscape Research (ZALF), Müncheberg, Germany

SIRIUS: A wheat simulation model that calculates biomass from intercepted photo-synthetically active radiation (PAR) and grain growth. Sirius has been calibrated for several modern wheat cultivars and is able to simulate crop growth accurately in a wide range of conditions, including Europe, NZ/Australia and USA and under climate change Accessed at http://www.rothamsted.ac.uk/mas-models/ sirius.php on 15 December 2014

\section{Software/graphics}

Mapping Software: yEd., yWorks GmbH, Vor dem Kreuzberg 28, 72070 Tübingen, Germany, www.yWorks.com 